\title{
Oxygen Electrode Degradation in Solid Oxide Cells Operating in Electrolysis and Fuel Cell Modes: LSCF Destabilization and Inter-Diffusion at the Electrode/Electrolyte Interface
}

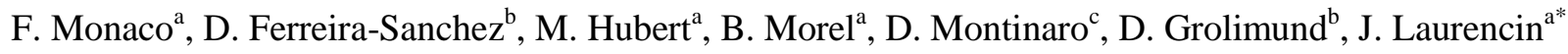 \\ ${ }^{a}$ Univ. Grenoble Alpes - CEA/LITEN, 38054, Grenoble, France \\ ${ }^{\mathrm{b}}$ Swiss Light Source, Paul Scherrer Institut, CH-5232 Villigen PSI, Switzerland \\ ${ }^{c}$ SOLIDpower S.p.A., 38017, Mezzolombardo, Italy
}

\begin{abstract}
Three long-term experiments have been performed in SOEC and SOFC modes at different operating temperatures. The durability tests confirm a higher degradation in electrolysis mode with respect to fuel cell operation. In addition, a larger increase of the ohmic resistance is observed for the cell operated at higher temperature in electrolysis mode. The oxygen electrodes of the pristine and tested cells have been characterized by synchrotron X-ray micro-diffraction and micro-fluorescence to assess the relation between the material destabilization and the formation of insulating phases due to interlayer diffusion. The analyses of the pristine cell confirm the presence after the electrode sintering of strontium zirconate and a Gd-rich inter-diffusional layer in the electrolyte just below the zirconates. Moreover, evolutions in the LSCF unit cell volume reveal strontium segregation after aging. The associated material destabilization is linked to the accumulation of $\mathrm{SrZrO}_{3}$ at the barrier layer-inter-diffusional layer interface in operation and both phenomena are found to be thermally-activated and promoted in electrolysis mode. Finally, the crystallographic evolution of the inter-diffusional layer in electrolysis mode has been investigated by X-ray diffraction. A slight increase of the phase peaks intensity detected at the highest temperature is correlated to the largest formation of $\mathrm{SrZrO}_{3}$ observed in this condition. Based on these preliminary results, it is proposed that the loss of $\mathrm{Zr}^{4+}$ from the electrolyte due to the zirconates formation could facilitate the inter-diffusion of $\mathrm{Gd}$, reducing the local ionic conductivity and thus significantly contributing to the largest increase in the ohmic resistance observed in this case.
\end{abstract}

Keywords: SOFC, SOEC, LSCF destabilization, strontium zirconate, interdiffusional layer.

*Corresponding author: Telephone: +33438 782210

E-mail: jerome.laurencin@cea.fr 


\section{Introduction}

In recent years, significant efforts have been devoted to free the energy sector from fossil based sources. With this objective, the transition towards a renewable based electricity system is required. However, one of the main difficulties for this change relies on the intermittent nature of renewable energy sources (RES), such as solar panels or wind turbines. Therefore, it is also necessary to develop technologies able to store the overproductions of RES and to reinject them in the grid when the demand exceeds the electric production. Among the different options, the use of hydrogen as an energy vector to compensate for RES fluctuations is considered as one of the most promising pessibilities.

Solid oxide cells (SOCs) are promising electrochemical reactor operating high temperatures. They offer many advantages such as high efficiency or a large fuel flexibility. Moreover, thanks to their reversibility, the same device can be used to produce electricity in fuel cell mode (solid oxide fuel cell - SOFC) or hydrogen in electrolysis mode (solid oxide electrolysis cell - SOEC) [1-3]. Typical materials for SOCs are zirconia doped with $8 \%$ mol. of yttria (referred as yttria-stabilized zirconia 8YSZ) for the dense electrolyte, a porous cermet of nickel and YSZ (Ni-YSZ cermet) for the hydrogen electrode, and mixed ionic and electronic conductors (MIECs) for the oxygen electrode. The use of MIECs allows extending the electrochemically active region to the whole electrode surface instead of being limited to the triple phase boundaries (TPBs), defined as the regions where the pores, the electronic conductive phase, and the ionic conductive phase meet. Among the different compounds for the oxygen electrode, lanthanum strontium cobalt ferrite $\left(\mathrm{La}_{\mathrm{x}} \mathrm{Sr}_{1-\mathrm{x}} \mathrm{Co}_{\mathrm{y}} \mathrm{Fe}_{1-}\right.$ $\mathrm{y}_{3-\delta}-\mathrm{LSCF}$ ) is the most common material for SOCs application [4-7]. It has been recently proposed to replace LSCF in the oxygen electrode by a composite of LSCF and gadolinium-doped ceria $\left(\mathrm{Gd}_{\mathrm{x}} \mathrm{Ce}_{1-\mathrm{x}} \mathrm{O}_{2-\delta}-\mathrm{GDC}\right)$, in order to mitigate the mismatch in thermal expansion coefficients between the different components [8] and to enhance the electrode performances, in particular in SOEC mode [9]. In addition, new types of microstructures, such as nanofibers, are currently being investigated for the oxygen electrode to optimize the electrode performances even at intermediate temperature [10].

Despite their numerous advantages, the degradation of SOCs is still too large to envisage the industrial deployment of this technology especially for electrolysis applications [11-14]. Indeed, the voltage degradation rates are still in the range of $\approx 0.1 \quad 3 \% \mathrm{kh}^{-1}$ in SOFC mode and between 0.6 and $10 \% \cdot \mathrm{kh}^{-1}$ in SOEC operation at relatively low current densities $\left(\left|\mathrm{i}_{\mathrm{DC}}\right|<1 \mathrm{~A} \cdot \mathrm{cm}^{-2}\right)[14]$ These rather large degradation rates are. The degradation is caused by various ageing phenomena activated by the high operating temperature and the polarization. In particular, an increase in the ohmic 
resistance of the cell has been reported $[15,16]$ as well as an augmentation of the polarization resistances of the two electrodes. In the hydrogen electrode, nickel tends to agglomerate during operation at high temperature resulting in a phase coarsening that compromises the electro-catalytic performances of the electrode [17]. In addition, in electrolysis mode, a migration of Ni from the interface with the electrolyte towards the bulk of the electrode has been reported [18-20]. In the oxygen electrode, the release of strontium from LSCF associated with the reactivity at the electrolyte interface are known to contribute significantly to the overall degradation in SOCs [2124]. The demixing of the LSCF under operation is associated to a passivation layer on the LSCF surface [25] and the formation of insulating phases, such as strontium zirconate $\left(\mathrm{SrZrO}_{3}\right)$, at the interface with the electrolyte [26-28].

It has been shown that the direct contact between the LSCF electrode material and the YSZ electrolyte favors the strontium segregation due to the high reactivity between the two materials $[29,30]$. To mitigate this reactivity, a barrier layer of GDC is usually added between the electrolyte and the electrode avoiding the direct contact between the two [31,32]. As a consequence, an interdiffusional layer (IDL) has been detected between the GDC and the YSZ [33,34] which is reported to have a lower ionic conductivity [35]. Nowadays, the effects of the IDL on the cell performances and its evolution during operation are still unclear. It has been proposed that the IDL could be formed exclusively during sintering $[27,36]$ and it could even act as a protective layer to prevent the formation of strontium zirconate $[33,37,38]$ whereas some other authors have suggested that the evolution in operation of the IDL could contribute to the increase of the ohmic losses in SOCs $[39,40]$.

Even in presence of the GDC barrier layer, the formation of $\mathrm{SrZrO}_{3}$ is still detected in aged [41] and pristine cells [31], especially in the porosities of the barrier layer [24]. For the pristine cells, it appears that the electrode sintering temperature may play a key role in the strontium zirconate formation [42]. For the aged cells, it has been recently pointed out that this phenomenon could be significantly accelerated in electrolysis mode [24,43-45]. Based on this observation, it has been proposed that this behavior could be associated to the depletion of oxygen vacancies in the LSCF material in anodic polarization [24]. In particular, the accumulation of oxygen in the LSCF under electrolysis current could be the driving force for $\mathrm{Sr}$ segregation and the formation of a passivation layer of strontium oxide $(\mathrm{SrO})$ on the electrode surface [24]. Subsequently, the $\mathrm{Sr}$ could form volatile species and diffuse in the porosity of the electrode and barrier layer to react with the zirconium coming from the electrolyte resulting in the formation of the insulating $\mathrm{SrZrO}_{3}$ phase. 
However, for a full validation of this mechanism there is not yet a direct and clear experimental evidence showing the severity of the LSCF phase demixing and its correlation with the formation of $\mathrm{SrZrO}_{3}$ as a function of the operating conditions (i.e. polarization and operating temperature). Moreover, the real impact of the oxygen electrode degradation on the evolution of the IDL is still unclear.

In this work, the LSCF destabilization, the strontium zirconate formation, and the IDL evolution after ageing are investigated using a classical hydrogen electrode supported cell. Two cells have been operated in electrolysis mode in the same experimental conditions changing only the operating temperature between the two tests. These two durability experiments have been used to investigate the influence of the operating temperature on the degradation in SOEC mode. Besides, a third cell has been tested in fuel cell mode for a very long operating time to compare the degradation as a function of the polarization. Specimens have been taken from the cells and advanced post mortem eharacterizations have been carried out on the extracted samples. In particular, micro. Micro X-ray diffraction $(\mu \mathrm{XRD})$ and micro X-ray fluorescence ( $\mu \mathrm{XRF}) 2 \mathrm{D}$ maps have been acquired from specimens extracted at the oxygen electrode side to analyze the crystallographic modifications in the LSCF and the chemical reactivity at the barrier layer/electrolyte interface. These characterizations have been complemented by classical scanning electron microscopy (SEM) observations and energy-dispersive X-ray (EDX) analyses. Based on the experimental results, the impact of the operating conditions on the LSCF demixing has been assessed and a possible evolution of the IDL has been discussed.

\section{Materials and Methods}

\subsection{Cells Description}

Typical hydrogen supported cells have been used for this study. They are composed of a dense electrolyte made of $8 \mathrm{YSZ}$ having a thickness of $\approx 8 \mu \mathrm{m}$ sandwiched between the two electrodes. The hydrogen electrode consists in a thick Ni-YSZ porous cermet $(\approx 260 \mu \mathrm{m})$ whereas the oxygen electrode has a multilayer structure with a total thickness of $\approx 60 \mu \mathrm{m}$. This assembly is composed of a LSCF-GDC $\left(\mathrm{La}_{0.6} \mathrm{Sr}_{0.4} \mathrm{Co}_{0.2} \mathrm{Fe}_{0.8} \mathrm{O}_{3-\delta}-\mathrm{Gd}_{0.2} \mathrm{Ce}_{0.8} \mathrm{O}_{2-\delta}\right)$ composite $(\approx 16 \mu \mathrm{m})$ associated to a LSCF layer $(\approx 20 \mu \mathrm{m})$ topped with a current collector made of lanthanum strontium cobaltite $\left(\mathrm{La}_{0.5} \mathrm{Sr}_{0.5} \mathrm{CoO}_{3}, \mathrm{LSC}\right)$. Finally, a barrier layer of GDC of $\approx 4 \mu \mathrm{m}$ is added between the oxygen electrode and the electrolyte. 
The cells denoted Cell-1 and Cell-2 thereafter have a circular shape and an active area of $9.08 \mathrm{~cm}^{2}$, whereas Cell-3 presents a rectangular shape and an active area of $70 \mathrm{~cm}^{2}$. As described in Monaco et al. [18], the oxygen electrode of Cell-3 is segmented in 20 sectors with the external and central ones of $3.17 \mathrm{~cm}^{2}$ and $3.79 \mathrm{~cm}^{2}$, respectively. It is worth noting that, although their shapes are different, the three cells have been produced using the same manufacturing protocol and are identical in terms of composition and microstructures. To complement the study, a pristine cell (Reference Cell) of the same type has also been characterized.

\subsection{Experimental Setups and Testing Protocols}

\subsubsection{Description of the Test Benches}

The two experiments in electrolysis mode (Cell-1 and Cell-2) have been performed in an in-house setup depicted in Figure 1a.

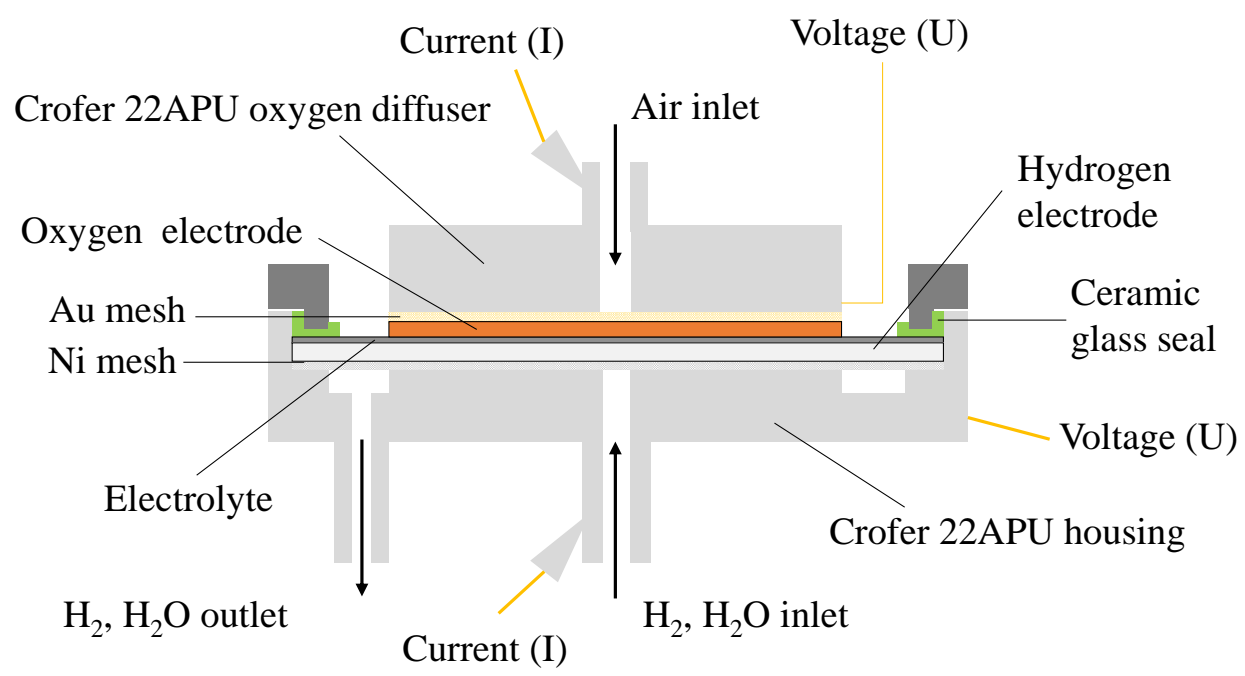

a)

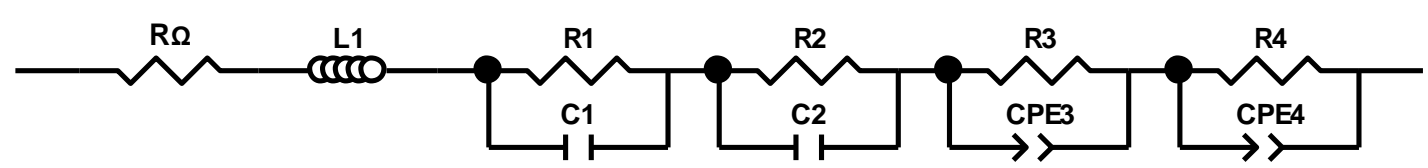

b)

Figure 1: a) Experimental setup used for Cell-1 and Cell-2 - b) Equivalent circuit model used to analyze the EIS spectra obtained under polarization in electrolysis mode.

The test bench is equipped with a Crofer22APU oxygen diffuser, positioned on top of the oxygen electrode, which serves also as current collector. To ensure a good electrical contact and a homogeneous flow path, a gold grid of 100 meshes $\cdot \mathrm{cm}^{-2}$ with a diameter of $34 \mathrm{~mm}$ was inserted 
between the diffuser and the oxygen electrode surface. A gold wire welded on the pipe close to the grid was used to measure the cell voltage whereas the current was applied directly on the metallic inlet pipe (cf. Figure 1a). The cell holder at the hydrogen side was also made of Crofer22APU and a $\mathrm{Ni}$ grid of 100 meshes $\mathrm{cm}^{-2}$ has been chosen as current collector in contact with the hydrogen electrode. As for the oxygen electrode, a gold wire welded directly to the Crofer22APU support close to the $\mathrm{Ni}$ grid, has been used to measure the cell voltage whereas the current was applied from the metallic pipe (Figure 1a). To ensure the gas tightness and the electrical insulation between the two electrodes, a ceramic glass seal is deposited at the periphery of the electrolyte. Finally, a loading of $0.4 \mathrm{~kg} \cdot \mathrm{cm}^{-2}$ has been applied on the cell to minimize the contact resistances.

At the inlet of the hydrogen electrode, steam was produced using a steam generator kept in saturated vapor conditions. The steam flow was regulated downstream thanks to a modified mass flow controller (MFC), allowing its operating temperature to be higher than $100{ }^{\circ} \mathrm{C}$. A second mass flow controller was used for the hydrogen, and the two fluxes were mixed in the inlet pipe before entering the cell housing. Finally, the outlet gas was sent to a heat exchanger to separate the water from the dry gas.

The cell aged in fuel cell mode (Cell-3) was tested in a specific setup with a longitudinal co-flow configuration that has already been described in Monaco et al. [18]. In this setup, the different segments of the oxygen electrode are connected to a metallic plate having the same structure. The different metallic sectors have been electrically insulated by using a non-conductive glue, allowing measuring the local voltages and current densities for each sector independently.

\subsubsection{Experimental Protocols}

For Cell-1 and Cell-2, after the reduction of the nickel oxide in the cermet, the polarization curves (i-U curves) at $800{ }^{\circ} \mathrm{C}$ were measured in fuel cell mode sending $100 \% \mathrm{H}_{2}$ at the hydrogen electrode (flowrate $=6 \mathrm{Nml} \cdot \mathrm{min}^{-1} \cdot \mathrm{cm}^{-2}$ ). Synthetic air was sent to the oxygen electrode and its flowrate was chosen to have an equivalent air utilization factor of $20 \%$ at $\left|i_{\mathrm{DC}}\right|=0.75 \mathrm{~A} \cdot \mathrm{cm}^{-2}$ for the entire duration of the experiment. After this preliminary characterization, the temperature was increased to $850{ }^{\circ} \mathrm{C}$ and the gas composition in the hydrogen side was changed to $\mathrm{H}_{2} \mathrm{O} / \mathrm{H}_{2}=90 / 10$ vol. $\%$ while raising the total flowrate to $12 \mathrm{Nml} \cdot \mathrm{min}^{-1} \cdot \mathrm{cm}^{-2}$. Once the open circuit voltage $(\mathrm{OCV})$ was stabilized, the $\mathrm{i}-\mathrm{U}$ curves in electrolysis mode, and the electrochemical impedance spectra (EIS) at $\mathrm{i}_{\mathrm{DC}}=-0.75$ $\mathrm{A} \cdot \mathrm{cm}^{-2}$ were measured. Subsequently, the two durability experiments were conducted. For Cell-1, the temperature was kept at $850^{\circ} \mathrm{C}$ and the current was set to $-0.75 \mathrm{~A} \cdot \mathrm{cm}^{-2}$. For Cell-2, instead, the 
temperature was lowered to $750{ }^{\circ} \mathrm{C}$ keeping the cell at OCV. After the stabilization of the temperature and the voltage, the same current as for Cell-1 was applied. During the ageing, the two cells have been operated in galvanostatic mode for $\approx 1$ ' 800 hours and the evolution of the voltage in each experiment has been recorded every 15 minutes. At the end of the durability experiments, the two cells have been characterized again at $850^{\circ} \mathrm{C}$ measuring the EIS at $i_{D C}=-0.75 \mathrm{~A} \cdot \mathrm{cm}^{-2}$. This last step has been performed to investigate the evolution of the ohmic and polarization resistances $\left(\mathrm{R}_{\Omega}\right.$ and $\mathrm{R}_{\mathrm{p}}$, respectively) after ageing in the same conditions of current and gas composition for the two cells. It can be noticed that the heating from $750{ }^{\circ} \mathrm{C}$ to $850{ }^{\circ} \mathrm{C}$ for Cell-2 was done keeping the cell at $\mathrm{OCV}$.

The EIS under polarization at the beginning and at the end of the durability experiments have been measured in the frequency range between $10^{-2}$ and $10^{5} \mathrm{~Hz}$ in galvanostatic mode with an amplitude of $\pm 40 \mathrm{~mA} \cdot \mathrm{cm}^{-2}$. For both cells, the amplitude of the sinusoidal current has been selected paying a specific attention to check the linearity condition and to reduce the signal-to-noise ratio. In addition, since SOCs operate at high temperature, a classical inductive effect of the wires is typically measured at high frequencies modifying the shape of the impedance spectra and hindering the determination of the ohmic resistance [51,52]. To overcome this limitation, one typical approach is to fit the impedance spectra using an equivalent circuits model (ECM) [46] representative of the cell response (i.e. with an inductive contribution) and to re-simulate the impedance without this inductive component. It is worth noting that several types of ECMs exist that are used to represent the different factors contributing to the cell response, such as gas diffusion, gas conversion, chargetransfer reactions and solid-state diffusion. In order to determine the most suitable ECM, recent works have been using the distribution of relaxation time (DRT) to identify the different electrochemical processes starting from the frequency response [47-50]. In our case, to remove the inductance and to evaluate the ohmic and polarization resistances, a similar ECM to the one reported in [53,54] has been employed as shown in Figure 1b. It consists of an inductance (L), that takes into account the contribution of the wires, an ohmic resistance $\left(\mathrm{R}_{\Omega}\right)$, two resistancecapacitance elements (R-C) and two resistance-constant phase element groups (R-CPE). The two RCs are used to simulate the low-frequency contributions in the diagrams whereas the R-CPEs represent the phenomena at medium/high frequencies. It can be noticed that in this case, the DRT was not used to distinguish between the various contributions to the polarization resistance because the interest was mainly in the separation between the ohmic and polarization resistances. 
In parallel, the segmented cell tested in fuel cell mode (Cell-3) was aged for 15'000 hours at an operating temperature of $780{ }^{\circ} \mathrm{C}$ [18]. A nominal flowrate of $\approx 7 \mathrm{Nml} \cdot \mathrm{min}^{-1} \cdot \mathrm{cm}^{-2}$ composed of diluted $\mathrm{H}_{2}$ was used to supply the hydrogen electrode $\left(\mathrm{H}_{2} / \mathrm{N}_{2}=60 / 40\right.$ vol.\%), whereas ambient air was sent to the oxygen electrode (flowrate $\approx 110 \mathrm{Nml} \cdot \mathrm{min}^{-1} \cdot \mathrm{cm}^{-2}$ ). During the durability experiment, the cell was kept at OCV or operated in potentiostatic mode. In addition, the evolution of the area specific resistance (ASR) at $\mathrm{i}_{\mathrm{DC}} \approx 0.25 \mathrm{~A} \cdot \mathrm{cm}^{-2}$ was measured periodically to follow the overall cell degradation.

All the electrochemical characterizations have been conducted using a potentiostat/galvanostat (Autolab PGSTAT-302N) equipped with a frequency response analyzed module and a 10 A current booster. All the experimental data have been collected using the $\mathrm{NOVA}^{\circledR}$ software and analyzed using Zview ${ }^{\circledR}$.

\subsection{Characterization Techniques}

After the durability experiments, the physico-chemical evolutions between the electrolyte and the oxygen electrode have been investigated as a function of the ageing conditions. In particular, synchrotron-based $\mu \mathrm{XRD}$ and $\mu \mathrm{XRF}$ characterizations have been performed at the microXAS beamline of the Swiss Light Source (SLS) to analyze the crystalline and chemical evolution as a function of the operating conditions. On the one hand, samples extracted from Cell-1 and Cell-2 have been characterized after ageing in electrolysis mode to examine the impact of the operating temperature on the LSCF destabilization and the reactivity at the electrolyte interface. On the other hand, a specimen extracted from Cell-3 aged in fuel cell mode has been analyzed to assess the effect of polarization. To complete the study, a last sample taken from the pristine cell (Reference Cell) has been examined to study the reactivity at the oxygen electrode/barrier layer/electrolyte interfaces after sintering and to compare the evolutions before and after ageing. All the specimens for the synchrotron-based characterization have been extracted from the cells center, taking thin lamellae containing the oxygen electrode, the barrier layer, and the electrolyte. Finally, SEM-EDX analyses have been also performed on Cell-1 and Cell-2 to compare the strontium zirconate formation after ageing in electrolysis mode.

\subsubsection{Sample Preparation for the $\mu X R D / \mu X R F$ Analysis}

As shown in Figure 2, the lamellae for the $\mu \mathrm{XRD} / \mu \mathrm{XRF}$ characterization have been prepared using a $\mathrm{Xe}^{+}$plasma-Focused Ion Beam (pFIB) Vion $\left(\mathrm{FEI}^{\mathrm{TM}}\right)$, following a similar protocol as in Khamidi 
et al. [55]. Fragments extracted from the aged and pristine cells have been positioned in the vacuum chamber of the pFIB machine to prepare the lamellae. A rectangular platinum layer (thickness $\approx 3-4$ $\mu \mathrm{m}$ ) was deposited on the sample surface to protect the region of interest (ROI) (Figure 2a) [56]. This step was carried out using a low current of $59 \mathrm{nA}$, to ensure the deposition of Pt while preventing any damaging of the specimen surface. Subsequently, the two sides of the ROI were milled to isolate the lamella (Figure 2b). This step was done at two different currents, $470 \mathrm{nA}$ in the area far from the ROI and at a lower current of $180 \mathrm{nA}$ in the proximity to the ROI to avoid any material damaging in the sample. Once the lamella was isolated (Figure 2c), a small Pt deposition was used to fix it on a specific micromanipulator and the sample was detached from the cell using a low ion current of $180 \mathrm{nA}$ (Figure 2d). Finally, a last Pt deposition was used to glue the lamella to an aluminum pin (Figure 2e) and the sample was removed from the vacuum chamber. The final dimensions for all the specimens are approximately $100 \times 80 \times 20 \mu \mathrm{m}^{3}$ for the horizontal dimension $(\mathrm{X})$, the vertical dimension $(\mathrm{Y})$ and the depth $(\mathrm{Z})$, respectively. This geometry allows investigating a representative zone along the interface while the thickness of the samples has been chosen as a tradeoff between the X-ray absorption and the need to probe enough crystallographic grains to obtain well-defined powder-like diffraction rings.

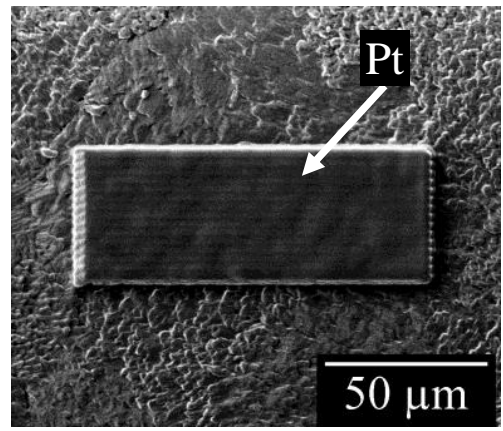

a)

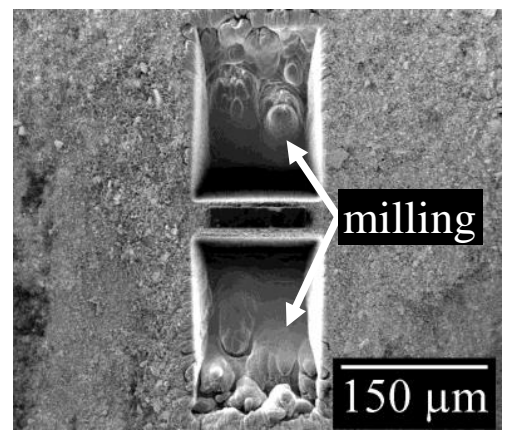

b)

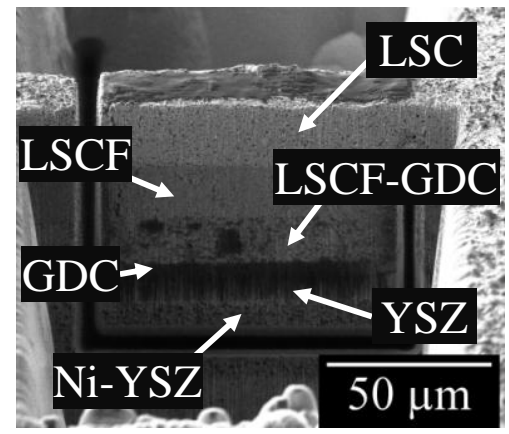

c)

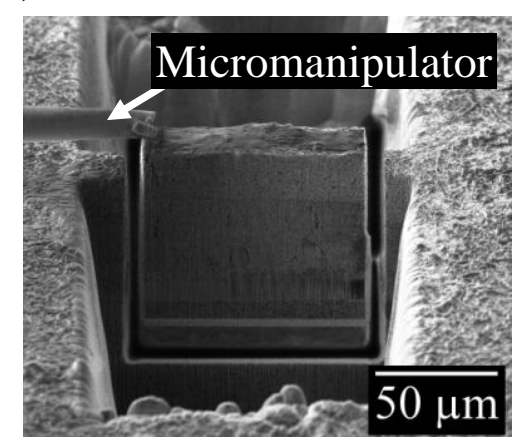

d)

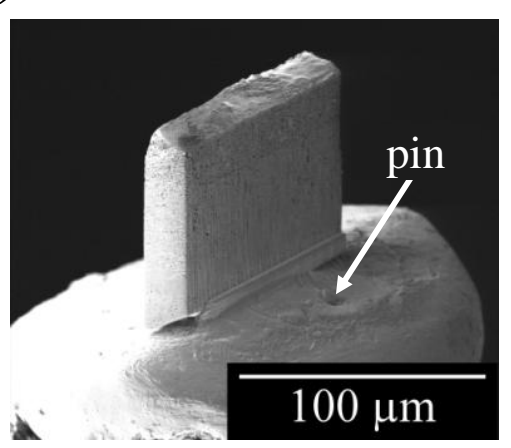

e)

Figure 2: Illustration of the lamellae preparation procedure: a) Pt deposition on the ROI surface - b) FIB milling around the ROI - c) Isolated lamella illustrating the cell multilayered structure (in particular for the oxygen electrode) - d) Extraction of the specimen - e) Finalized sample. 


\subsubsection{Synchrotron-Based $\mu X R D / \mu X R F$ Characterization}

The setup of the microXAS beamline at the SLS is described schematically in Figure 3. During the characterization, the specimens have been illuminated with an X-rays beam focused using two Kirkpatrick-Baez (KB) mirrors (photon flux: $10^{11} \mathrm{ph} \cdot \mathrm{s}^{-1}$ ). The experiment was performed at 17.2 $\mathrm{keV}$ with a beam size on the sample of around $1 \times 0.5 \mu \mathrm{m}^{2}$. Therefore, the vertical spatial resolution (Y axis, cf. Figure 3) is around $500 \mathrm{~nm}$. The lamellae have been positioned on a motorized holder in the focal point of the X-rays beam and 2D raster scans have been performed on the vertical (Y) and longitudinal $(\mathrm{X})$ directions with a step size of $500 \mathrm{~nm}$ all over each sample. A silicon drift diode detector (KETEK), positioned at $\approx 90^{\circ}$ from the X-ray beam, has been used to detect the fluorescence spectrum of the illuminated region of the specimen. In parallel, a $2 \mathrm{D}$ diffraction detector (PILATUS 100K) positioned behind the samples has been used to obtain the local XRD, as a cumulated information along the depth of the sample (in the direction of the X-rays). The acquisition of the diffracted X-rays has been possible thanks to the limited thickness of the specimens along the beam direction $(\mathrm{Z})$ allowing the transmission of X-rays towards the detector. The two detectors allow obtaining at the same time the elemental and crystalline 2D maps of each lamella.

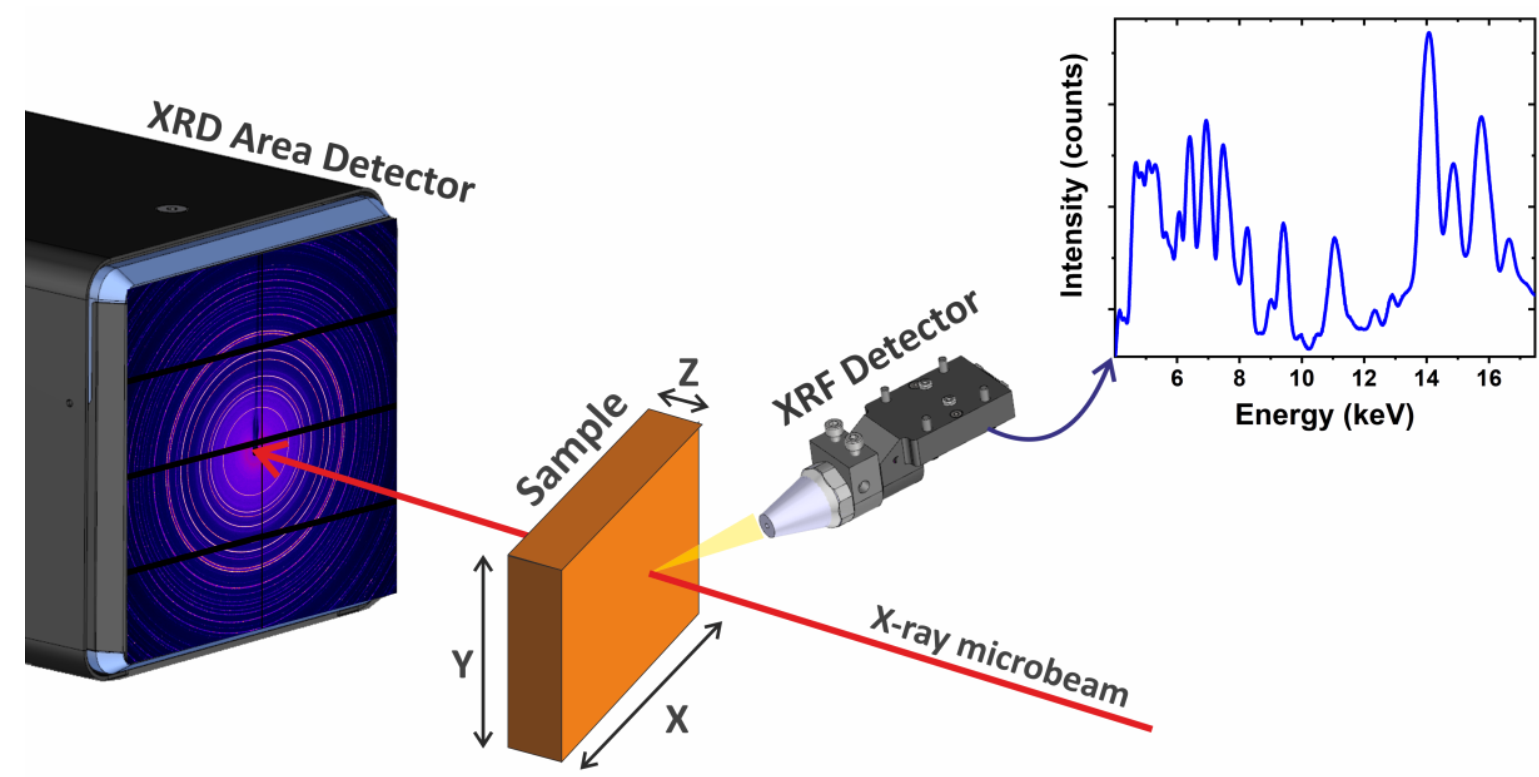

Figure 3: Experimental setup at the microXAS beamline in which the sample is scanned along the XY directions while recording simultaneously the local fluorescence spectra and the local powder-like diffraction pattern.

The 2D diffraction rings measured in each point have been azimuthally integrated using pyFAI [57] to obtain classical 1D diffraction patterns, whereas the local fluorescence data have been fitted using pyMCA [58]. The $\mu \mathrm{XRF}$ and $\mu \mathrm{XRD}$ data are subsequently integrated over the horizontal direction to obtain an average elemental composition and diffraction pattern for each vertical 
position in the sample. The Rietveld refinement of these local XRD patterns has been performed using the software XRDUA [59].

\subsubsection{SEM-EDX Observations}

In complementarity with the $\mu \mathrm{XRD} / \mu \mathrm{XRF}$ analyses, the two cells aged in electrolysis mode (Cell-1 and Cell-2) have been characterized using a field emission gun - scanning electron microscope (FEG-SEM Zeiss Merlin, Germany) equipped with an energy-dispersive X-ray detector (EDX, Brucker XFlash Detector). Before the observations, fragments of the cells have been obtained perpendicular to the oxygen electrode/barrier layer/electrolyte interface. Then, they have been impregnated in polymer resin (Epofix, Denmark) to fill the pores and the surfaces have been polished until a final stage using a diamond spray at $0.25 \mu \mathrm{m}$. A thin carbon coating has been done on the polished cross-section to avoid charging effects of the samples during microscopy observations. The SEM images have been obtained using a secondary electron detector at working distance between $8-10 \mathrm{~mm}$ and an accelerating voltage of $3 \mathrm{kV}$. For the EDX analysis, the accelerating voltage was increased to $15 \mathrm{kV}$ whereas the working distance was not changed.

\section{Results and Discussion}

\subsection{Experimental Results}

\subsubsection{Cells Aged in Electrolysis Mode}

The experimental results obtained for Cell-1 and Cell-2 are reported in Figure 4. To ensure the same starting point between the two durability experiments, it has been checked that the two cell presents the same initial performances. The i-U curves obtained in $\mathrm{SOFC}$ at $800{ }^{\circ} \mathrm{C}$ after the reduction of the $\mathrm{NiO}$ in the cermet are compared in Figure 4a. The two i-U curves are well superposed indicating that the cells exhibit almost identical performances. Moreover, the OCV values obtained in the two cases (1.16 V and 1.15 V for Cell-1 and Cell-2, respectively) are comparable to the theoretical one (which corresponds to $1.2 \mathrm{~V}$ at $800^{\circ} \mathrm{C}$ if considering $99.6 \%$ of $\mathrm{H}_{2}$ in the hydrogen side) indicating that there is no significant gas leakage between one electrode and the other.

After this preliminary characterization, the temperature was increased to $850{ }^{\circ} \mathrm{C}$ and the performances in electrolysis mode have been measured for both cells with a gas composition of $\mathrm{H}_{2} \mathrm{O} / \mathrm{H}_{2}=90 / 10$ vol.\% (Figure 4b). In these conditions, the OCV values are almost identical (0.807 $\mathrm{V}$ for Cell-1 and $0.805 \mathrm{~V}$ for Cell-2). In addition, the two cells exhibit a similar behavior in terms of 
i-U curves being perfectly superposed up to $i_{D C}=-0.5 \mathrm{~A} \cdot \mathrm{cm}^{-2}$ whereas only a minor difference is found at higher current density (for $\left|i_{D C}\right|>0.5 \mathrm{~A} \cdot \mathrm{cm}^{-2}$ ). As an example, from the polarization curves in Figure $4 b$, it can be noticed that Cell-2 presents slightly better performances at $\mathrm{i}_{\mathrm{DC}}=-0.75 \mathrm{~A} \cdot \mathrm{cm}^{-2}$ ( $\mathrm{U}_{\text {Cell-2 }}$ is $17 \mathrm{mV}$ lower than $\mathrm{U}_{\text {Cell-1 }}$ corresponding to a difference of $\approx 2 \%$ ). Comparing the initial impedance diagrams (Figure $4 \mathrm{~d}$ and Figure $4 \mathrm{e}$ ), this difference can be attributed to the lowfrequency processes ( $f<1 \mathrm{~Hz}$ ). This phenomenon may be linked to the gas diffusion in the electrodes $[50,51]$ that could be associated to some minor differences in the hydrogen electrodes microstructures. Nevertheless, it can be considered that the performances at the beginning of the tests are the same for the two cells. 


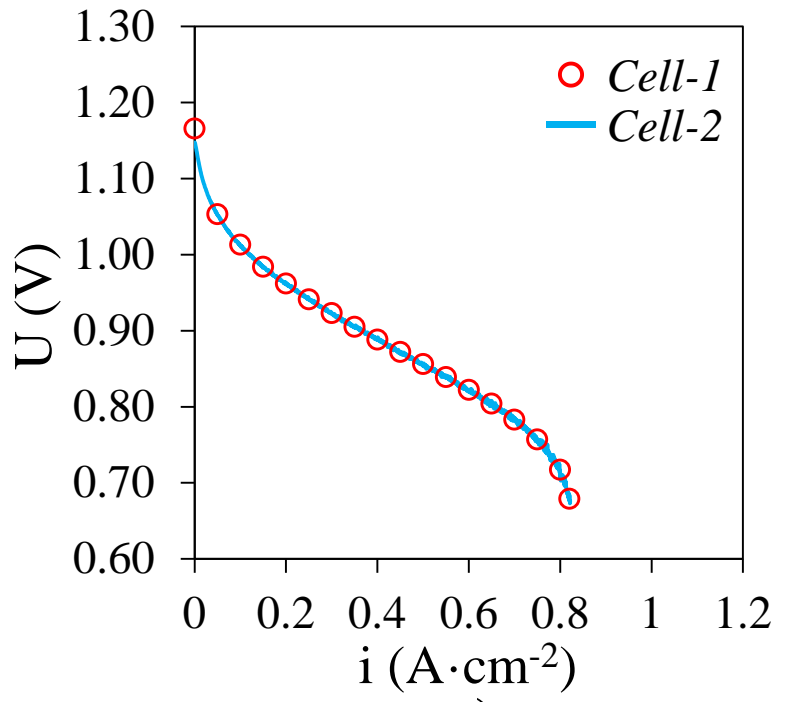

a)

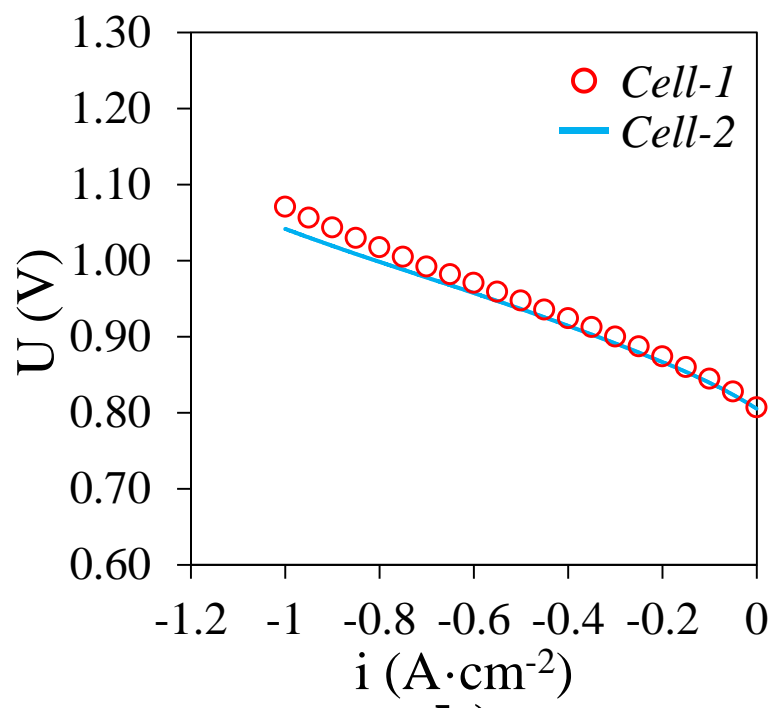

b)

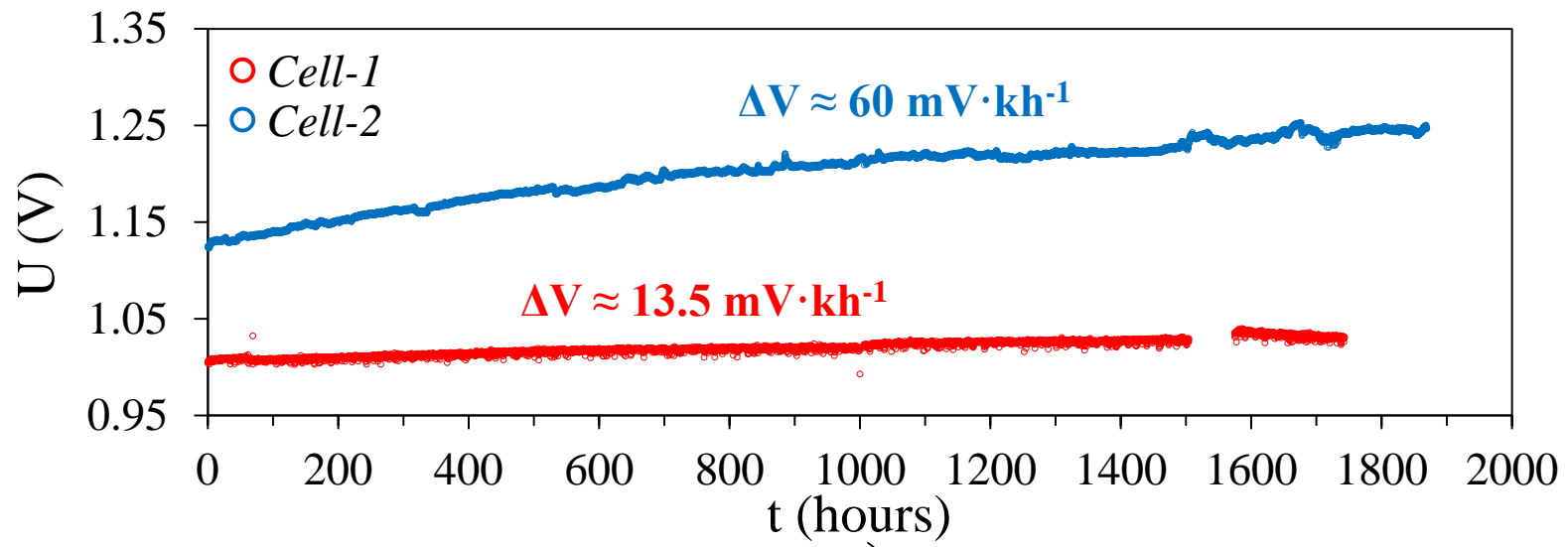

c)
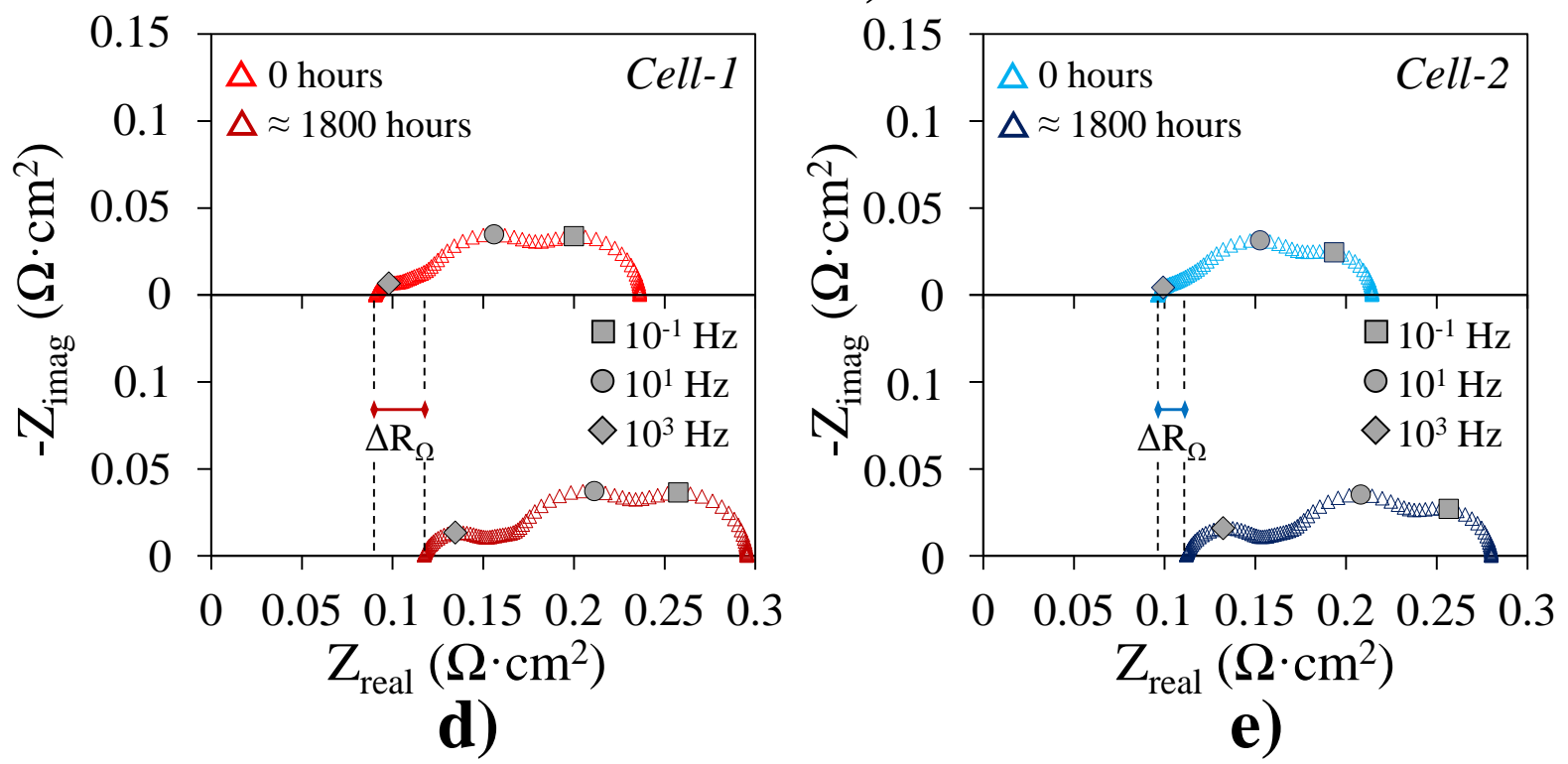

Figure 4: Experimental results for Cell-1 and Cell-2: a) Initial performances of the cells in SOFC mode at $800{ }^{\circ} \mathrm{C}-$ b) Initial performances of the cells in SOEC mode at $850{ }^{\circ} \mathrm{C}-\mathrm{c}$ ) Durability curves at 850 ${ }^{\circ} \mathrm{C}(\mathrm{Cell}-1)$ and $750{ }^{\circ} \mathrm{C}(\mathrm{Cell}-2)$ - d) and e) EIS acquired under polarization at $850{ }^{\circ} \mathrm{C}$ at the beginning and at the end of the long-term test for Cell-1 and Cell-2, respectively. 
After the assessment of the initial performances, the durability experiments were conducted and the recorded degradation curves are reported in Figure 4c, in which the evolutions of the cell voltage (at $i_{D C}=-0.75 \mathrm{~A} \cdot \mathrm{cm}^{-2}$ ) are plotted as a function of the ageing time. The degradation, measured as the slope of the durability curves $(\mathrm{U}=\mathrm{f}(\mathrm{t}))$, is significantly higher for Cell-2 aged at $750{ }^{\circ} \mathrm{C}$ with an overall degradation rate of $\approx 60 \mathrm{mV} \cdot \mathrm{kh}^{-1}$. On the other hand, the measured degradation rate of Cell1 tested at $850{ }^{\circ} \mathrm{C}$ is substantially lower $\left(\approx 13.5 \mathrm{mV} \cdot \mathrm{kh}^{-1}\right)$. As can be seen in the graph, for Cell- 1 after $\approx 1$ '500 hours of operation a problem with the electrical power supply of the test bench has caused the temporary interruption of the degradation test for approximately 80 hours. However, when the test was restarted, after a stabilization period, the cell performances were in the same range as during the first 1'500 hours of ageing (Figure 4c).

To evaluate the effects of the degradation on the ohmic and polarization resistances, the impedance diagrams under current at $850^{\circ} \mathrm{C}$ have been measured at the end of each test and compared with the initial ones (Figure 4d and Figure 4e). As a first observation, it is noted that, when the cells are characterized in the same conditions, the difference in the degradation of the total ASR $\left(=R_{\Omega}+R_{p}\right)$ is much less pronounced than what the analysis of the durability curves would have suggested. This result is consistent with those reported by Fang et al. who have found a higher measured degradation rates at lower temperature but comparable ASR degradations in the same conditions when operating a short-stack at $700{ }^{\circ} \mathrm{C}, 750{ }^{\circ} \mathrm{C}$ and $800{ }^{\circ} \mathrm{C}$ [60]. As discussed in Hubert et al. [17], this type of behavior could be explained by considering the thermally-activated response of the cell. Indeed, it is worth reminding that the activation overpotentials and the ohmic losses are significantly larger at lower temperature. Therefore, the impact of the material deterioration on the cell performance depends on the temperature. In other words, the same material degradation will induce a higher loss of cell performances at lower temperature. These observations reinforce the statements reported in Hubert et al. [17] in which it has been indicated that the performance degradation should be compared in the same experimental conditions.

For both cells, the most impacted contributions in the impedance diagrams after the correction of inductance effect, appear to be the ohmic resistances the high frequency arc $\left(>10^{3} \mathrm{~Hz}\right.$ ) (Figure $4 \mathrm{~d}$ and Figure 4e). In particular, a significant increase in the ohmic resistance can be detected, which is higher for the cell aged at $850{ }^{\circ} \mathrm{C}\left(\right.$ Cell-1, $\Delta \mathrm{R}_{\Omega}=15 \mathrm{~m} \Omega \cdot \mathrm{cm}^{-2} \cdot \mathrm{kh}^{-1}$ or $\left.17 \% \cdot \mathrm{kh}^{-1}\right)$ than for the one aged at $750{ }^{\circ} \mathrm{C}\left(\right.$ Cell $-2, \Delta \mathrm{R}_{\Omega}=8.5 \mathrm{~m} \Omega \cdot \mathrm{cm}^{-2} \cdot \mathrm{kh}^{-1}$ or $\left.9 \% \cdot \mathrm{kh}^{-1}\right)$. This augmentation of the ohmic resistance may originate from different phenomena. It could be mainly ascribed to either a full $\mathrm{Ni}$ depletion at the $\mathrm{H}_{2}$ electrode $[61,62]$ or an evolution of the IDL at the barrier layer/electrolyte 
interface $[39,63]$. However, SEM observations of the hydrogen electrode have revealed that $\mathrm{Ni}$ is still present at the electrolyte interface after ageing and remains percolated. Therefore, in our specific case, no severe Ni depletion is present after the durability experiments. Moreover, previous studies conducted on the same type of cells, have revealed that there is not a fully depleted layer of nickel at the hydrogen electrode/electrolyte interface even after ageing in electrolysis mode for more than 10'000 hours $[18,64]$. Therefore, it could be suspected that, for our tested cells, the increase in the ohmic resistance may be mainly due to an evolution of the inter-diffusional layer during the durability experiments in electrolysis mode.

\subsubsection{Cell Aged in Fuel Cell Mode}

The results of the durability test for Cell-3 have been already discussed in Monaco et al. [18]. Therefore, only the main aspects are detailed hereafter. During the experiment, a limited evolution of the local currents in potentiostatic mode has been measured indicating a good stability of the cell even after $15^{\prime} 000$ hours. In addition, the periodical measurements of the global ASR at $\approx 0.25$ $\mathrm{A} \cdot \mathrm{cm}^{-2}$ have shown an overall increase of the resistance of $\approx 9 \mathrm{~m} \Omega \cdot \mathrm{cm}^{2} \cdot \mathrm{kh}^{-1}$ corresponding to an equivalent degradation rate of $\approx 3 \mathrm{mV} \cdot \mathrm{kh}^{-1}$. This rather low degradation rate after many thousands of hours of test in fuel cell mode is consistent with other results reported in literature for very long durability experiments [65-69]. This type of evolution indicates that the degradation phenomena are milder in these conditions compared to an operation in electrolysis mode. In particular, lower degradation in the oxygen electrode could be expected in this case.

\subsection{Post-Mortem Analyses}

The impedance diagrams analyses for the cell aged in electrolysis mode (Cell-1 and Cell-2) have revealed a larger increase of the ohmic resistance for the one operated at higher operating temperature. This increase in the ohmic resistance may be partially associated to a modification of the IDL between the GDC and the 8YSZ under operation [39,63]. Besides, the low degradation rate for the cell aged in fuel cell mode for 15'000 hours (Cell-3) suggests that the physico-chemical evolutions at the oxygen electrode would be less severe for this cell.

To verify these statements, $\mu \mathrm{XRD} / \mu \mathrm{XRF}$ and SEM-EDX characterizations have been performed on the samples. In particular, the LSCF decomposition and the formation of $\mathrm{SrZrO}_{3}$ at the electrolyte interface have been investigated as a function of the operating conditions. In addition, a specific attention has been paid to highlight a modification of the IDL after operation in electrolysis mode. 
As a first step, the oxygen electrode of the pristine cell (Reference Cell) has been analyzed to investigate the precipitation of strontium zirconate and the interdiffusion at the interface between the barrier layer and the electrolyte during the cell manufacturing.

\subsubsection{Characterization of the Reference Cell}

In Figure 5a, 2D maps showing the normalized elemental distribution in the active layer of strontium $(\mathrm{Sr})$, cerium $(\mathrm{Ce})$, gadolinium $(\mathrm{Gd})$ and yttrium $(\mathrm{Y})$ are given for the pristine cell. According to the XRF signal, a small amount of $\mathrm{Sr}$ is detected along the interface between the GDC barrier layer and the $8 Y S Z$ electrolyte. The diffusion of strontium is also revealed in Figure $5 \mathrm{~b}$ in which the normalized XRF intensities integrated along the horizontal direction are given for each vertical position. This result indicates that during the sintering of the LSCF electrode, strontium can diffuse through the GDC and react at the barrier layer/electrolyte interface. To verify the crystalline phase of the Sr-based compound, the average XRD pattern obtained at the interface is plotted in Figure $5 \mathrm{c}$. As it can be seen, three peaks at $13.66^{\circ}, 19.38^{\circ}$ and $23.78^{\circ}$ are detected corresponding to the (011), (020) and (121) reflections of the perovskite structure of $\mathrm{SrZrO}_{3}$. Therefore, as already observed by several authors $[27,31,70]$, it is confirmed that the Sr diffusion during the sintering yields to the formation of strontium zirconate at the interface between GDC and 8YSZ.

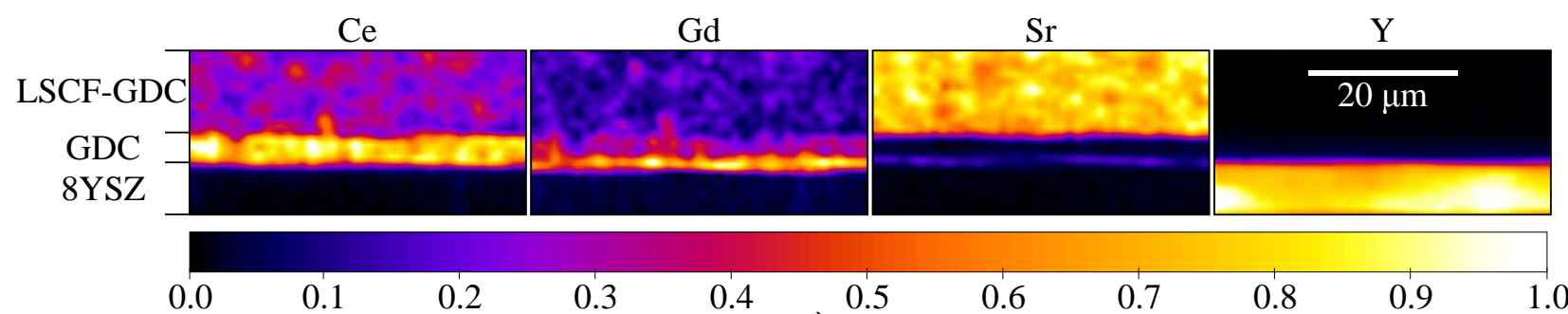

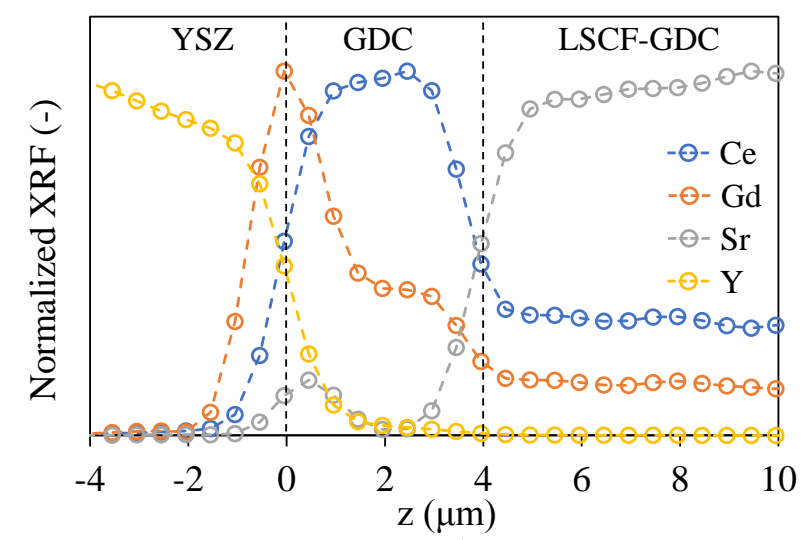

b) a)

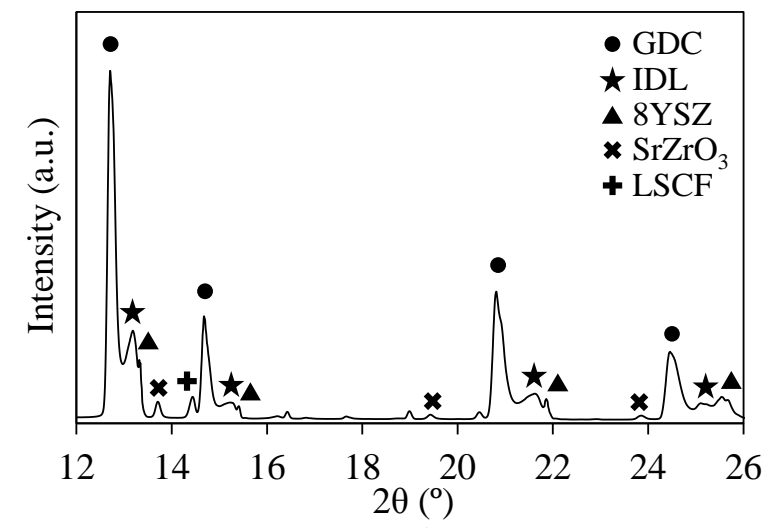

c)

Figure 5: Characterization of the pristine oxygen electrode: a) Normalized 2D element distribution obtained from the XRF signal at the electrode/barrier layer/electrolyte interface - b) Local XRF intensity integrated over the horizontal direction - c) XRD pattern at the GDC/8YSZ interface. 
From the XRF data given in Figure 5a and Figure 5b, it can be also seen that the distribution of gadolinium is significantly different with respect to the cerium with an accumulation of $\mathrm{Gd}$ in the region close to the GDC/8YSZ interface just below the zirconates. This high Gd concentration could be due to its dissolution in the YSZ resulting in the formation of the thin IDL in the electrolyte. This claim is consistent with the results reported in literature [27,33,70-72], in which a thin layer containing a relatively high concentration of $\mathrm{Gd}$ was also observed at the electrolyte interface after sintering.

The diffraction pattern acquired at the electrolyte interface (Figure 6a) has been also used to characterize this inter-diffusional layer. The analysis of the XRD pattern has allowed identifying a crystalline phase whose main peaks are detected at $13.15^{\circ}, 15.20^{\circ}, 21.56^{\circ}$ and $25.33^{\circ}$. Interestingly, all these peaks are close and slightly shifted with respect to the peaks of the 8YSZ (found at $13.33^{\circ}$, $15.41^{\circ}, 21.86^{\circ}$ and $25.69^{\circ}$ for the (111), (020), (022) and (131) reflections, respectively). This simple shift indicates that the IDL presents the same cubic structure than the fluorite 8YSZ but with a different unit cell volume (UCV). This observation was confirmed by the estimation of the lattice parameter obtained by Rietveld refinement. Indeed, it has been found that the lattice parameter for this crystalline phase at the interface is slightly higher than the one measured for the 8YSZ in the bulk of the electrolyte $(\approx 5.20 \AA$ vs $5.14 \AA$ ). Moreover, it can be mentioned that the $2 \mathrm{D}$ diffraction patterns obtained at the interface have a well-defined ring-like shape contrarily to the spotty diffractograms obtained in the bulk of the electrolyte (which are associated to the relatively large crystals of the 8YSZ, cf. Figure $6 \mathrm{~b}$ ).

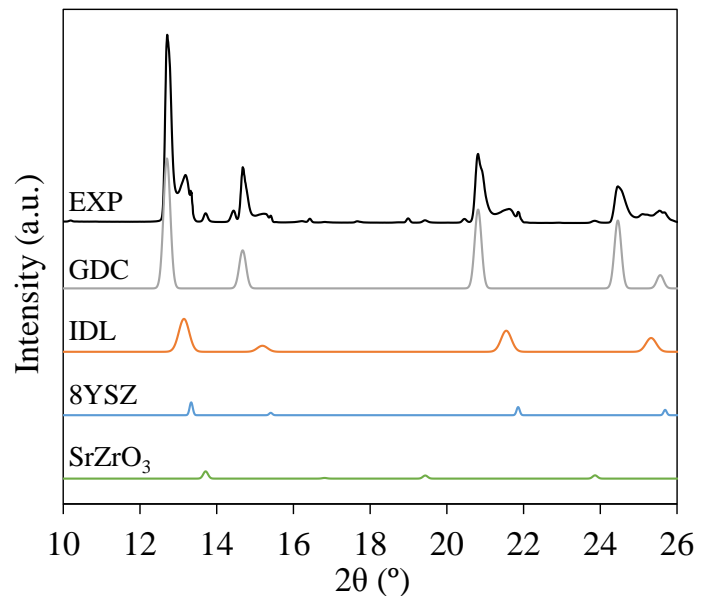

a)

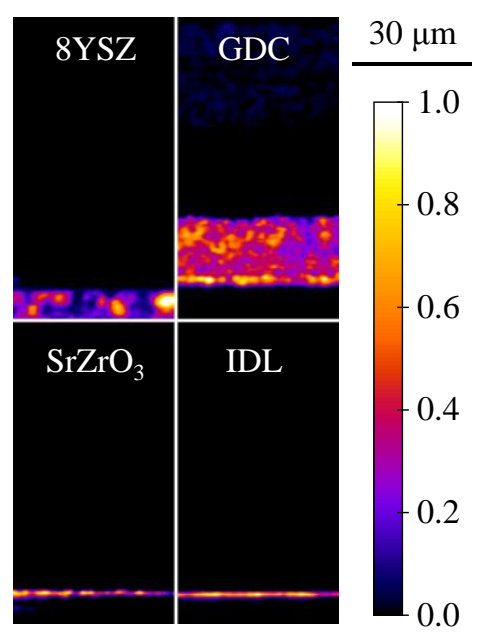

b)

Figure 6: Analysis of the XRD pattern at the interface for the Reference Cell: a) Main crystalline phases identified at the barrier layer/electrolyte interface - b) 2D maps of the XRD showing the normalized distribution of the crystalline phases (note that the intensity variation of 8YSZ is not 
related to the spatial distribution but is explained by the preferred orientation of the relatively large grains for this phase).

All the aforementioned characterizations by $\mu \mathrm{XRF}$ and $\mu \mathrm{XRD}$ are fully consistent with the $\mathrm{Gd}$ diffusion in YSZ resulting in a solid solution corresponding to the IDL formation during sintering. Indeed, the insertion of $\mathrm{Gd}$ in the $\mathrm{Y}_{2} \mathrm{O}_{3}$-doped $\mathrm{ZrO}_{2}$ has been reported to favor the crystallization of nanoscale-grains [73], which could explain the powder diffraction-like 2D patterns measured experimentally for the IDL. Moreover, the larger lattice parameter for the IDL could be due to the bigger ionic radius of $\mathrm{Gd}$ with respect to $\mathrm{Y}[74,75]$. Therefore, it can be reasonably stated that the crystalline phase ascribed to the IDL could correspond to a $\mathrm{Gd}_{2} \mathrm{O}_{3}-\mathrm{Y}_{2} \mathrm{O}_{3}-\mathrm{ZrO}_{2}$ solid solution exhibiting nano-grains and cubic fluorite-type crystal similar to the ones reported in [76-79].

To confirm the localization of the inter-diffusional layer, the spatial distribution of the crystalline phases has been deduced from the XRD maps by identifying the peaks corresponding to the GDC, the 8YSZ, the IDL and the $\mathrm{SrZrO}_{3}$. These distributions are shown in Figure $6 \mathrm{~b}$ across the barrier layer including part of the electrolyte and the electrode. Firstly, the barrier layer and the electrolyte can be clearly distinguished as they are ascribed to the GDC and 8YSZ, respectively. Secondly, the zirconate corresponds to the line at the interface between the GDC and 8YSZ. Finally, the close examination of the maps shows that the IDL is a fine layer of less than $1 \mu \mathrm{m}$ (thickness $\approx 500 \mathrm{~nm}$ ) located just below the zirconates. This confirms the formation of the solid solution in the electrolyte just at the interface with the barrier layer. Besides, this observation means that, in this case, the interdiffusion between the GDC and the $8 \mathrm{YSZ}$ does not prevent the formation of $\mathrm{SrZrO}_{3}$ as it has been reported for different types of IDL forming at different sintering temperatures $[33,37,38]$.Therefore, for this type of cells, the presence of this IDL after sintering presents mainly negative effects on the cell performances as it causes a decrease in the ionic conductivity $[36,79,80]$ without avoiding entirely the reactivity between the $\mathrm{Sr}$ and the $\mathrm{Zr}$ from the electrolyte.

\subsubsection{Characterization of the Aged Cells}

\subsubsection{Destabilization of the $\mathrm{LSCF}$ and $\mathrm{SrZrO}_{3}$ Formation}

In order to quantify the destabilization of the oxygen electrode material after ageing, the evolution of the unit cell volume of the LSCF along the electrode thickness has been estimated by Rietveld refinement (space group R-3c) for the different cells as shown in Figure 7. Indeed, the loss of Sr from the LSCF structure is expected to cause an increase of the UCV [81-83]. Therefore, this 
parameter could be a relevant indicator to highlight the LSCF demixing according to equation (1) [24].

$$
\operatorname{Sr}_{L a}^{\prime}(L S C F)+O_{O}^{x}(L S C F) \rightarrow S r O_{L S C F, s u r f}+V_{L a}^{\prime \prime \prime}(L S C F)+V_{O}^{\bullet \bullet}(L S C F)
$$

Comparing the Reference Cell to Cell-1 (Figure 7a and Figure 7b, respectively), an overall increase of the UCV is found across the active layer (LSCF-GDC) and the pure LSCF layer (UCV max $_{2} \approx 53$ $\AA^{3}$ for Cell-1 and $\approx 351 \AA^{3}$ for the pristine cell). On the other hand, Cell-2 presents an increase of $\mathrm{UCV}$ that appears to be less significant as can be seen in Figure $7 \mathrm{c}\left(\mathrm{UCV}_{\max } \approx 352 \AA^{3}\right)$. In addition, in this case the increase of UCV is found to be limited to the composite layer in a region close to the interface with the GDC barrier layer (whereas the UCV in the LSCF layer remains similar to the one of the Reference Cell). These observations would suggest that a significant destabilization of the LSCF would occur in electrolysis mode when the cell is operated at higher temperature (Cell-1, $\left.850{ }^{\circ} \mathrm{C}\right)$. In contrast, the $\mathrm{Sr}$ release appears to be much more limited and restricted to the electrochemical active zone for Cell-2 aged at lower temperature $\left(750{ }^{\circ} \mathrm{C}\right)$. Finally, the electrode destabilization of Cell-3 aged in fuel cell mode for a very long time of $15^{\prime} 000$ hours at $780{ }^{\circ} \mathrm{C}$ is roughly the same than the one found for Cell-2 aged at around the same temperature for a shorter time (1'800 hours) as shown in Figure 7d. Therefore, it could be concluded that the destabilization is favored under electrolysis current as expected. Moreover, it would be aggravated at high temperature.
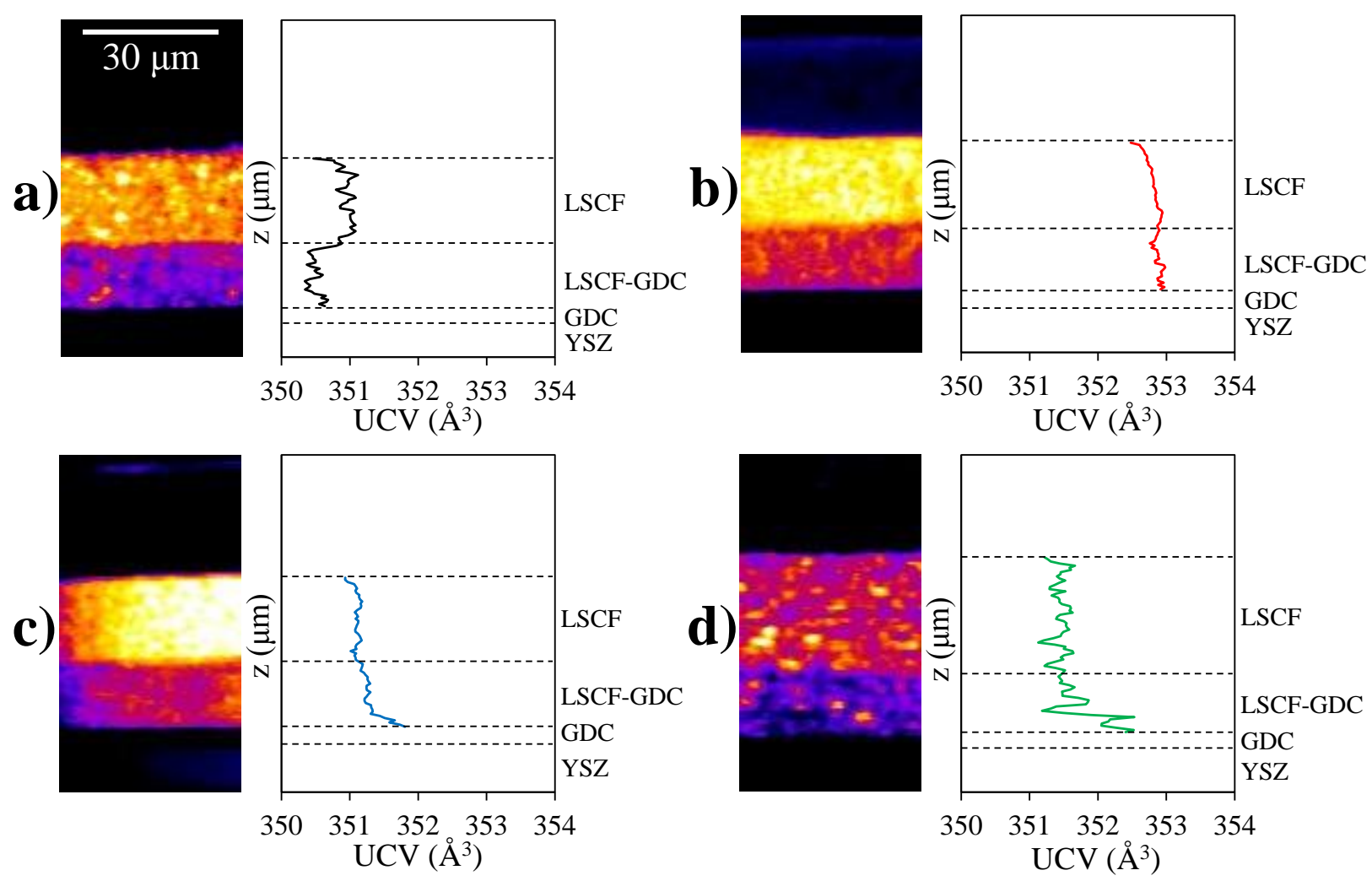
Figure 7: 2D XRD maps of the LSCF phase and evolution of the LSCF unit cell volume along the oxygen electrode thickness for the four samples analyzed: a) Reference Cell - b) Cell-1 - c) Cell-2 - d) Cell-3.

To check the diffusion of $\mathrm{Sr}$ towards the electrolyte, the normalized XRF signals from the electrode-barrier layer/electrolyte area have been considered and the 2D maps showing the distributions of Gd, Sr and Y are given in Figure 8a. The XRF maps show a clear signal of Sr, detected at the interface between the GDC and the 8YSZ for all the samples (Figure 8a). To quantify the amount of $\mathrm{Sr}$ at the barrier layer/electrolyte interface, the XRF signal has been integrated along the direction parallel to the electrolyte interface. The normalized integrated profiles are plotted in Figure 8b as a function of the position across the LSCF-GDC electrode, the barrier layer and a part of the electrolyte. A clear evolution of Sr content can be detected depending on the operating conditions. Indeed, after ageing in electrolysis mode at $850{ }^{\circ} \mathrm{C}(\mathrm{Cell}-1)$, the accumulation of $\mathrm{Sr}$ at the GDC/8YSZ interface is more than double with respect to the pristine cell, consistently with the higher release of Sr from the LSCF detected from the UCV evolution. Besides, the amount of $\mathrm{Sr}$ at the interface in the two cells aged in electrolysis mode at $750{ }^{\circ} \mathrm{C}(\mathrm{Cell}-2)$ and in fuel cell mode at $780{ }^{\circ} \mathrm{C}($ Cell-3) is quite similar and only slightly higher than the Reference Cell. Once again, this is in good agreement with the limited destabilization of the LSCF highlighted by the UCV estimations for these two samples. 


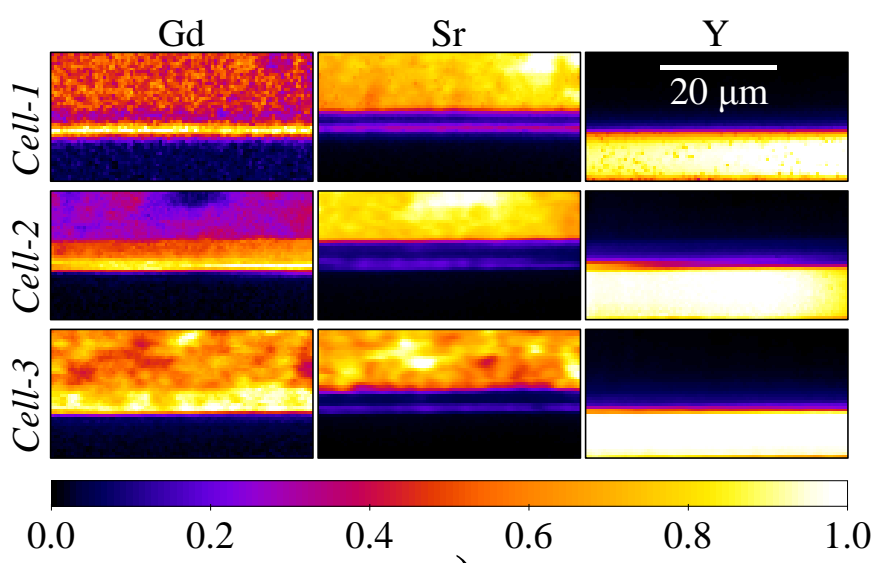

a)

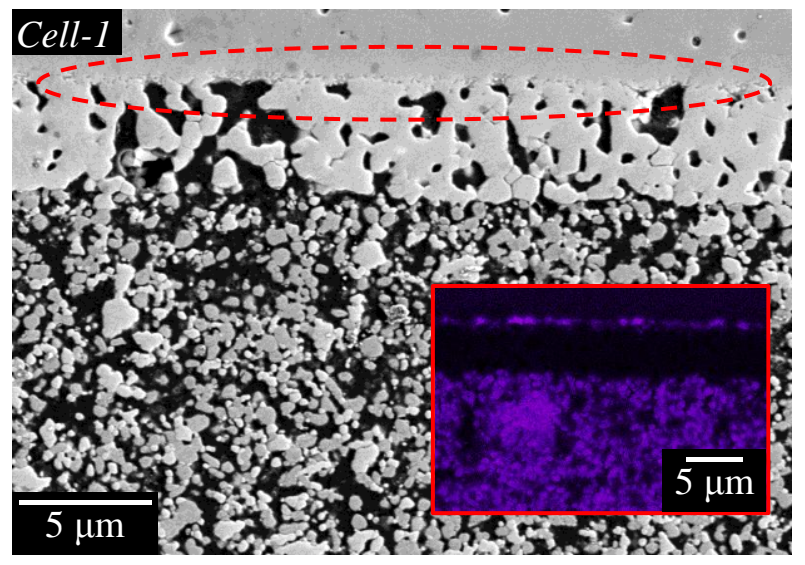

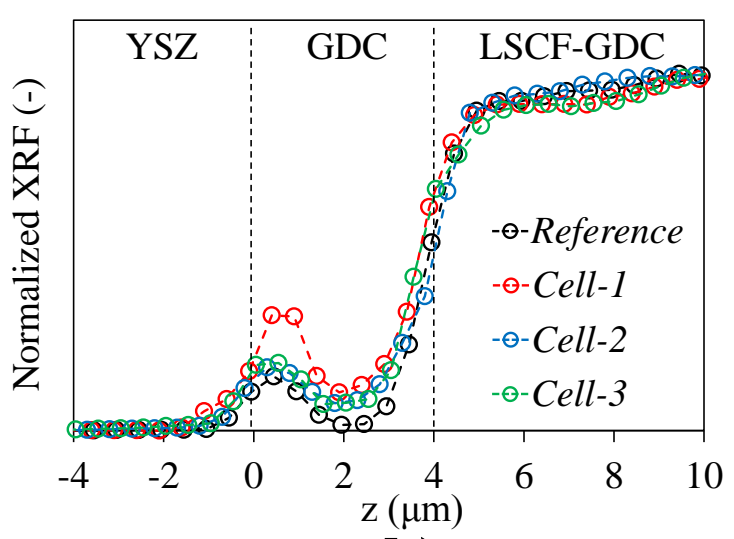

b)

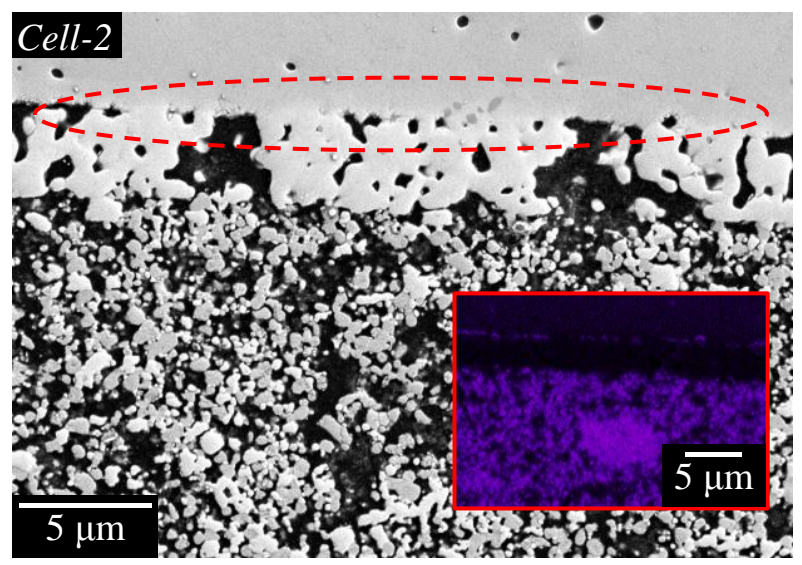

c)

Figure 8: Analysis of the operated cells: a) Normalized 2D element distribution obtained from the XRF signal at the electrode/barrier layer/electrolyte interface for Cell-1, Cell-2, and Cell-3 - b) Comparison of the integrated XRF signal of $\mathrm{Sr}$ between the pristine cell and the aged samples - c) SEM images of the LSCF-GDC/GDC/8YSZ region for the cells aged in electrolysis mode at $850{ }^{\circ} \mathrm{C}$ (Cell-1) and at $750^{\circ} \mathrm{C}(\mathrm{Cell}-2)$, the inserts show the EDX signal of $\mathrm{Sr}$ in the same interface.

This observation (i.e. $\mathrm{Sr}_{\text {Cell-2 }} \approx \mathrm{Sr}_{\text {Cell-3 }}$ at the interface) would confirm that the process of LSCF destabilization and the following formation of $\mathrm{SrZrO}_{3}$ is favored in electrolysis mode as proposed by Laurencin et al. [24]. Indeed, these two cells (Cell-2 and Cell-3) present similar evolutions but the operating times are significantly different indicating that roughly the same extent of LSCF destabilization and $\mathrm{SrZrO}_{3}$ formation have occurred after 1'800 hours in electrolysis mode at $750{ }^{\circ} \mathrm{C}$ and $15^{\prime} 000$ hours in fuel cell mode at $780^{\circ} \mathrm{C}$. Furthermore, the important changes in UCV and the large XRF signal for Sr found at the barrier layer/electrolyte interface for the cell operated at higher temperature (Cell-1) mean that the process of LSCF destabilization associated with the formation of zirconates is thermally activated.

This statement is also reinforced by the SEM-EDX observations of the oxygen electrode/barrier layer/electrolyte interfaces performed on the two cells aged in electrolysis mode (Figure 8c). 
Indeed, the presence of a secondary phase is clearly observed in the cross section of Cell- 1 at the GDC/8YSZ interface especially in the porosities of the barrier layer (i.e. in the region highlighted in red in Figure 8c where this secondary phase exhibits a different contrast in the secondary electrons images). On the contrary, the quantity of this phase is found to be less significant in the micrograph of Cell-2 (Figure 8c). The EDX analyses of the same regions (shown in the inserts of Figure 8c) have shown that this phase corresponds to a Sr-rich material that can be ascribed to the $\mathrm{SrZrO}_{3}$. Therefore, the SEM-EDX analyses confirms the larger accumulation of $\mathrm{Sr}$ at the interface for the cell aged at higher temperature.

Based on these results, it can be stated that the Sr release from the LSCF appears to be favored by the anodic polarization confirming the observations already discussed in Laurencin et al. [24]. In addition, it has been found that the kinetic rate of the Sr excorporation reaction (equation (1)) would be strongly thermally activated, so that operating the cell at high temperature would result in an acceleration of the LSCF demixing and $\mathrm{Sr}$ accumulation at the barrier layer/electrolyte interface. Therefore, the stronger destabilization of the LSCF material coupled with the nickel migration which is also observed after ageing in electrolysis mode $[18, \mathrm{X}]$, could contribute to explain the larger degradation rates measured in SOEC mode with respect to the SOFC operation.

\subsubsection{Evolution of the Inter-Diffusional Layer After Ageing in Electrolysis Mode}

The formation of zirconates would cause a loss of $\mathrm{Zr}$ from the electrolyte which could in turn contribute to modify the composition of the IDL. In this frame, it can be noticed in Figure 8a that the distribution of gadolinium is not uniform for the operated cells with a clear increase at the interface with the electrolyte. It can also be observed that the accumulation of Gd would be the highest for Cell-1 operated at high temperature in electrolysis mode. Therefore, a combined effect between the loss of $\mathrm{Zr}$ due the $\mathrm{SrZrO}_{3}$ precipitation and the diffusion of $\mathrm{Gd}$ could be suspected for the IDL.

To verify this hypothesis, the spatial distributions at the oxygen electrode/barrier layer/electrolyte interface of the different crystalline phases (8YSZ, GDC, $\mathrm{SrZrO}_{3}$ and IDL) are plotted for Cell-1 and Cell-2 in Figure 9a. The maps for the 8YSZ and GDC allow identifying without ambiguity the electrolyte and the barrier layer, respectively. Moreover, the position of $\mathrm{SrZrO}_{3}$ and the IDL phases can be clearly identified, and it is confirmed that IDL is located in between the zirconates and the 8YSZ electrolyte. Finally, as for the pristine cell, the inhomogeneity in the signal for the 8YSZ is simply explained by the quite coarse crystallographic grains in the electrolyte. In comparison with 
the maps of the pristine cell given in Figure $6 b$, it can be noticed that the overall thickness of the IDL after operation remains in the order of a few hundreds of nanometers $(\approx 500 \mathrm{~nm})$. This size for the IDL corresponds to the vertical resolution of the microXAS beamline, making it hard to investigate the increase of the thickness of the inter-diffusional layer. This statement clearly indicates the need of post-test characterizations performed at the nanoscale to analyze in detail the local evolution of the inter-diffusional layer after ageing. Nevertheless, despite this limitation, a slightly higher intensity of the signal for the IDL peaks can be observed in the sample extracted from Cell-1 indicating a potential increase in the concentration of this solid solution especially after ageing at higher operating temperature (Figure 9a). Based on this observation, a preliminary analysis has been conducted to assess the possible evolution of the IDL crystalline phase that could be related to the $\mathrm{SrZrO}_{3}$ formation.

With this purpose, the diffraction patterns obtained at the GDC/8YSZ interface for Cell-1 and Cell2 are compared with the XRD of the pristine cell in Figure 9b and Figure 9c, respectively. All the peaks associated to the $\mathrm{SrZrO}_{3}$ are increased after ageing at high temperature $\left(\mathrm{Cell}-1\right.$ at $850{ }^{\circ} \mathrm{C}$, Figure $9 b$ ), whereas they remain closer to the pristine sample for the cell aged at lower temperature (Cell-2 at $750{ }^{\circ} \mathrm{C}$, Figure 9c). These evolutions are consistent with the analysis of the XRF signal obtained for the two cells confirming the aggravating effect of the high operating temperature on the formation of strontium zirconate associated with the accumulation of Sr. Besides, an evolution of the intensity of the IDL peaks is also detected. For Cell-1, all the peaks associated to the interdiffusional layer are slightly increased in intensity, suggesting a modification at the barrier layer/electrolyte interface with an increase in the amount of the solid solution. For Cell-2, instead, the peaks associated to the IDL are essentially superposed with the XRD pattern of the pristine cell (except the (111) reflection). This observation may suggest that in this case only a limited augmentation of the IDL is detected after ageing. 


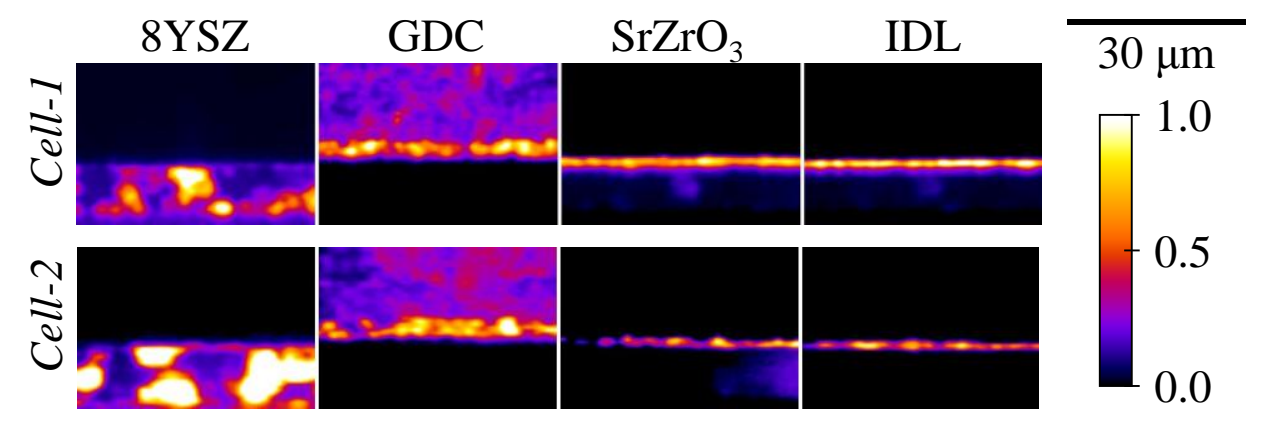

a)

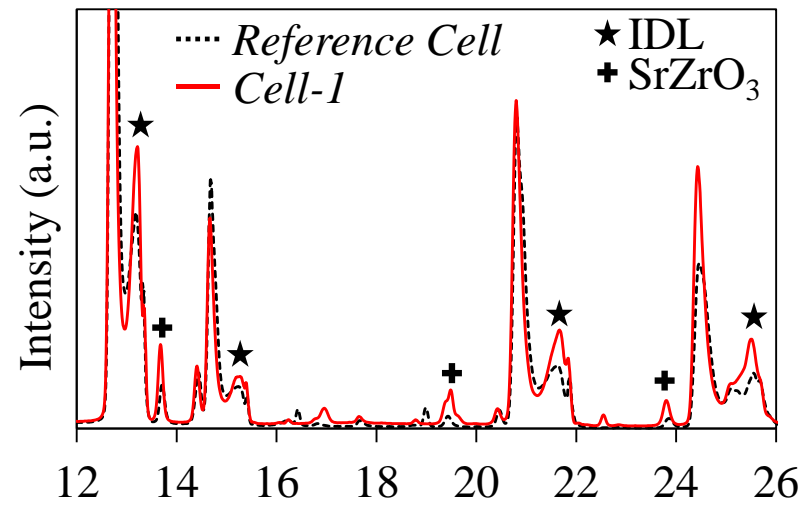
$2 \theta\left({ }^{\circ}\right)$

b)

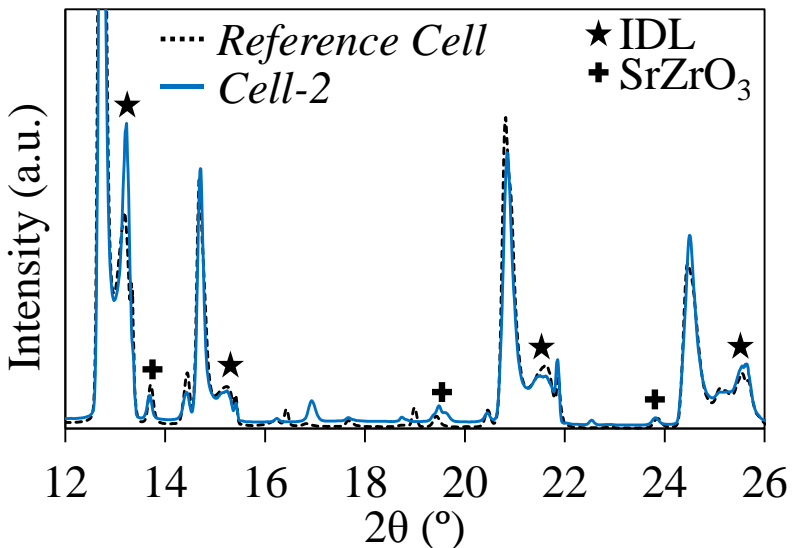

c)

Figure 9: Analysis of the evolution of the IDL after ageing in electrolysis mode: a) XRD maps exhibiting the crystalline phases at the interface between the barrier layer and the electrolyte for Cell1 and Cell-2 - b) and c) Evolution of the XRD pattern at the interface for the cells aged in electrolysis mode as a function of the operating temperature for Cell-1 and Cell-2, respectively.

Based on these results, it could be suspected that the IDL would evolve after operation especially at high temperature when the LSCF destabilization and the $\mathrm{SrZrO}_{3}$ formation are also aggravated. Therefore, this result could be an indication that the increase of the IDL at the interface is promoted by the formation of strontium zirconate. Indeed, it could be proposed that the loss of zirconium from the $8 \mathrm{YSZ}$ associated to the formation $\mathrm{SrZrO}_{3}$ could trigger the dissolution of gadolinium in the electrolyte via $\mathrm{Zr}^{4+}$ substitution [84]. It is worth noting that this proposition is quite in good agreement with the recent study of Matsui et al. [39] who have observed an evolution of the IDL after ageing by EDX analysis. Moreover, Villanova et al. have used nanoscale X-ray fluorescence to investigate the chemical evolutions after ageing of a hydrogen electrode supported cell $\left(\mathrm{i}_{\mathrm{DC}}=-\right.$ $0.75 \mathrm{~A} \cdot \mathrm{cm}^{-2}, \mathrm{~T} \approx 780^{\circ} \mathrm{C}, \mathrm{t} \approx 6^{\prime} 100$ hours $)$ and an electrolyte supported cell $\left(\mathrm{i}_{\mathrm{DC}}=-0.9 \mathrm{~A} \cdot \mathrm{cm}^{-2}, \mathrm{~T} \approx\right.$ $840^{\circ} \mathrm{C}, \mathrm{t} \approx 23^{\prime} 000$ hours) [70]. In their study, they have found no significant modification of gadolinium distribution at the GDC/8YSZ interface for the cell aged at lower temperature whereas an accumulation of $\mathrm{Gd}$ has been observed at the interface for the cell aged at higher temperature 
(although in this case the electrolyte was made of $6 / 1$ mol.\% scandia/ceria-doped zirconia $(6 \mathrm{Sc} 1 \mathrm{CeSZ}))$.

Finally, it is reminded that the loss of $\mathrm{Zr}$ and the enrichment in Gd reduce the conduction of oxygen ions in the IDL as measured by Matsui et al. [39]. These authors have synthetized several compounds, based on the local atomic compositions obtained by EDX at the GDC/8YSZ interface, and have shown that the interdiffusional process of $\mathrm{Gd}$ and $\mathrm{Zr}$ corresponds to an overall decrease of the ionic conductivity. Therefore, it can be reasonably proposed that the increase in ohmic resistances measured experimentally for Cell-1 and Cell-2 could be ascribed to an evolution of the IDL. In this frame, the higher increase in the ohmic resistance of Cell-1 with respect to Cell-2 would be consistent with a higher evolution of the IDL observed for this cell. Nevertheless, more characterizations at the nanoscale are still required to fully confirm and validate this mechanism.

\section{Conclusion}

In this work, the LSCF destabilization and the IDL evolution after ageing have been investigated as a function of the operating conditions. One durability experiment has been performed in fuel cell mode for a very long operating time and two long-term tests in electrolysis mode have been conducted keeping all the operating parameters identical except for the ageing temperature. Three long-term tests have been performed in fuel cell mode and in electrolysis mode at different operating temperatures. The experimental results have confirmed a larger degradation during electrolysis operation with respect to fuel cell mode. In addition, the degradation rate measured during the long term test in electrolysis mode has been found to be significantly larger at lower temperature. Moreover, in SOEC mode, the electrochemical characterizations in the same eonditions performed after the durability experiments have revealed an overall similar increase in the ASR and a larger increase of the ohmic resistance for the cell tested at higher eperating temperature.

After the durability experiments, samples extracted from the pristine and the aged cells have been characterized using synchrotron-based $\mu \mathrm{XRD} / \mu \mathrm{XRF}$ and SEM-EDX analyses. to assess the relation between the oxygen electrode destabilization, the formation of insulating species at the electrode/barrier layer/electrolyte interfaces, and the possible evolution of the inter-diffusionat layer. For the pristine cell, The analysis of the pristine cell has confirmed that the it has been confirmed that a reactivity between the electrode and the electrolyte occurs during the sintering 
resulting in the formation of strontium zirconate at the GDC/8YSZ interface between the GDC barrier layer and the 8YSZ electrolyte. Besides, the formation of a Gd-rich inter-diffusional layer has been detected in the electrolyte just below the zirconates. Based on the XRD analyses, it has been proposed that this inter-diffusional layer could correspond to a solid solution of $\mathrm{Gd}_{2} \mathrm{O}_{3}-\mathrm{Y}_{2} \mathrm{O}_{3}$ $\mathrm{ZrO}_{2}$ exhibiting a crystal structure similar to the $8 \mathrm{YSZ}$ but lower ionic conductivity.

The analysis of the aged cells has shown that the destabilization of the LSCF could be identified by an increase of the unit cell volume associated to the strontium release. This evolution has been found to be strongly dependent on the operating conditions. Indeed, it has been found that the LSCF destabilization and the Sr diffusion towards the electrolyte with the formation of strontium zirconate are promoted by both the high temperature and the operation in electrolysis mode, whereas it is significantly less severe under fuel cell operation. Furthermore, it has been demonstrated that the Sr release is promoted at high operating temperature. Moreover, it has been shown that Sr diffusion towards the electrolyte is - consistent with the LSCF destabilization, with a larger amount of strontium zirconate detected at the GDC/8YSZ interface after an operation in SOEC mode at higher As the LSCF decomposition has a direct impact on the performances, it has been concluded that the demixing of the exygen electrode material must also explain in part the higher degradation measured in SOEC operation.

Finally, the crystalline evolution of the IDL after the durability experiments in electrolysis mode has been preliminary investigated using the diffraction patterns measured at the barrier layer/electrolyte interface. A slightly stronger increase of the intensity for the XRD peaks of the solid solution has been observed after ageing at high temperature and this evolution has been ascribed to the larger formation of $\mathrm{SrZrO}_{3}$ in these conditions. Based on this behavior, it has been proposed that the loss of $\mathrm{Zr}^{4+}$ from the electrolyte associated to the $\mathrm{SrZrO}_{3}$ formation could facilitate the inter-diffusion of Gd reducing the local ionic conductivity. This mechanism could potentially explain a part of the larger increase in ohmic resistances observed for the cell operated in electrolysis mode at $850^{\circ} \mathrm{C}$. However, further characterizations at the nanoscale are required to finely investigate the IDL and its evolution after ageing.

\section{Acknowledgements}

This project has received funding from the Fuel Cells and Hydrogen 2 Joint Undertaking (JU) under grant agreement $n^{\circ} 825027$ (AD ASTRA project). The JU receives support from the European 
Union's Horizon 2020 research and innovation program and Denmark, France, Italy, Spain, Poland, Netherlands, Greece, Finland, Estonia, Germany, United Kingdom, Switzerland. F.M. received funding from the InnoEnergy PhD School Program and the European Institute of Technology (EIT). We would like to acknowledge the Paul Scherrer Institute (Villigen, Switzerland) for provision of synchrotron radiation beamtime at the microXAS beamline of the Swiss Light Source. The work has also been partially supported by the Carnot Institutes (CASSIOPEE project). 


\section{References}

[1] Godula-Jopek A, Millet P, Guillet N, Laurencin J, Mougin J, Bourasseau C, et al. Hydrogen Production by Electrolysis. Weinheim: Wiley-VCH; 2015.

[2] Lehner M, Tichler R, Koppe M. Power-to-Gas : Technology and Business Models. Springer. Springer; 2014. https://doi.org/10.1007/978-3-319-03995-4.

[3] Hauch A, Küngas R, Blennow P, Hansen AB, Hansen JB, Mathiesen B V., et al. Recent advances in solid oxide cell technology for electrolysis. Science (80- ) 2020;370. https://doi.org/10.1126/science.aba6118.

[4] Gómez SY, Hotza D. Current developments in reversible solid oxide fuel cells. Renew Sustain Energy Rev 2016;61:155-74. https://doi.org/10.1016/j.rser.2016.03.005.

[5] Laguna-Bercero MA. Recent advances in high temperature electrolysis using solid oxide fuel $\begin{array}{lllll}\text { cells: } & \text { A } & \text { review. } & \text { J }\end{array}$ https://doi.org/10.1016/j.jpowsour.2011.12.019.

[6] Menzler NH, Tietz F, Uhlenbruck S, Buchkremer HP, Stöver D. Materials and manufacturing technologies for solid oxide fuel cells. J Mater Sci 2010;45:3109-35. https://doi.org/10.1007/s10853-010-4279-9.

[7] Jiang SP. Development of lanthanum strontium cobalt ferrite perovskite electrodes of solid oxide fuel cells - A review. Int J Hydrogen Energy 2019;44:7448-93. https://doi.org/10.1016/j.ijhydene.2019.01.212.

[8] Dusastre V, Kilner JA. Optimisation of composite cathodes for intermediate temperature SOFC applications. Solid State Ionics 1999;126:163-74. https://doi.org/10.1016/S01672738(99)00108-3.

[9] Effori E, Moussaoui H, Monaco F, Sharma RKK, Debayle J, Gavet Y, et al. Reaction Mechanism and Impact of Microstructure on Performances for the LSCF-CGO Composite Electrode in Solid Oxide Cells. Fuel Cells 2019;19:429-44. https://doi.org/10.1002/fuce.201800185.

[10] Sanna C, Zhang W, Costamagna P, Holtappels P. Synthesis and electrochemical characterization of $\mathrm{La} 0.6 \mathrm{Sr} 0.4 \mathrm{Co} 0.2 \mathrm{Fe} 0.8 \mathrm{O} 3-\delta / \mathrm{Ce} 0.9 \mathrm{Gd} 0.1 \mathrm{O} 1.95$ co-electrospun nanofiber cathodes for intermediate-temperature solid oxide fuel cells. Int $\mathrm{J}$ Hydrogen Energy 2021;46:13818-31. https://doi.org/10.1016/j.ijhydene.2020.11.216.

[11] Irvine JTS, Neagu D, Verbraeken MC, Chatzichristodoulou C, Graves C, Mogensen MB. Evolution of the electrochemical interface in high-temperature fuel cells and electrolysers. Nat Energy 2016;1:1-13. https://doi.org/10.1038/nenergy.2015.14.

[12] Sohal MS, O’Brien JE, Stoots CM, Sharma VI, Yildiz B, Virkar A. Degradation Issues in 
Solid Oxide Cells During High Temperature Electrolysis. J Fuel Cell Sci Technol 2011;9:011017. https://doi.org/10.1115/1.4003787.

[13] Moçoteguy P, Brisse A. A review and comprehensive analysis of degradation mechanisms of solid oxide electrolysis cells. Int J Hydrogen Energy 2013;38:15887-902. https://doi.org/10.1016/j.ijhydene.2013.09.045.

[14] Skafte TL, Hjelm J, Blennow P, Graves C. Quantitative review of degradation and lifetime of solid oxide cells and stacks. EFCF Proc., Lucerne, Switzerland: 2016, p. B0501.

[15] Fang Q, Blum L, Menzler NH. Performance and Degradation of Solid Oxide Electrolysis Cells in Stack. J Electrochem Soc 2015;162:F907-12. https://doi.org/10.1149/2.0941508jes.

[16] Tietz F, Sebold D, Brisse A, Schefold J. Degradation phenomena in a solid oxide electrolysis cell after $9000 \mathrm{~h}$ of operation. J Power Sources 2013;223:129-35. https://doi.org/10.1016/j.jpowsour.2012.09.061.

[17] Hubert M, Laurencin J, Cloetens P, Morel B, Montinaro D, Lefebvre-Joud F. Impact of Nickel agglomeration on Solid Oxide Cell operated in fuel cell and electrolysis modes. J Power Sources 2018;397:240-51. https://doi.org/10.1016/j.jpowsour.2018.06.097.

[18] Monaco F, Hubert M, Vulliet J, Ouweltjes JPP, Montinaro D, Cloetens P, et al. Degradation of Ni-YSZ Electrodes in Solid Oxide Cells: Impact of Polarization and Initial Microstructure on the Ni Evolution. J Electrochem Soc 2019;166:F1229-42. https://doi.org/10.1149/2.1261915jes.

[19] Trini M, Hauch A, De Angelis S, Tong X, Hendriksen PV, Chen M. Comparison of microstructural evolution of fuel electrodes in solid oxide fuel cells and electrolysis cells. $\mathbf{J}$ Power Sources 2020;450:227599. https://doi.org/10.1016/j.jpowsour.2019.227599.

[20] Mogensen MB, Hauch A, Sun X, Chen M, Tao Y, Ebbesen SD, et al. Relation Between Ni Particle Shape Change and Ni Migration in Ni-YSZ Electrodes - a Hypothesis. Fuel Cells 2017;17:434-41. https://doi.org/10.1002/fuce.201600222.

[21] Knibbe R, Traulsen ML, Hauch A, Ebbesen SD, Mogensen M. Solid Oxide Electrolysis Cells: Degradation at High Current Densities. J Electrochem Soc 2010;157:B1209. https://doi.org/10.1149/1.3447752.

[22] Liu Y, Chen K, Zhao L, Chi B, Pu J, Jiang SP, et al. Performance stability and degradation mechanism of $\mathrm{La} 0.6 \mathrm{Sr} 0.4 \mathrm{Co} 0.2 \mathrm{Fe} 0.8 \mathrm{O} 3-\delta$ cathodes under solid oxide fuel cells operation conditions. Int J Hydrogen Energy 2014;39:15868-76. https://doi.org/10.1016/j.ijhydene.2014.03.077.

[23] Oh D, Gostovic D, Wachsman ED. Mechanism of La 0.6Sr 0.4Co 0.2Fe 0.8O 3 cathode degradation. J Mater Res 2012;27:1992-9. https://doi.org/10.1557/jmr.2012.222. 
[24] Laurencin J, Hubert M, Sanchez DF, Pylypko S, Morales M, Morata A, et al. Degradation mechanism of $\mathrm{La} 0.6 \mathrm{Sr} 0.4 \mathrm{Co} 0.2 \mathrm{Fe} 0.8 \mathrm{O} 3-\delta / \mathrm{Gd} 0.1 \mathrm{Ce} 0.9 \mathrm{O} 2-\delta$ composite electrode operated under solid oxide electrolysis and fuel cell conditions. Electrochim Acta 2017;241:459-76. https://doi.org/10.1016/j.electacta.2017.05.011.

[25] Baqué LC, Soldati AL, Teixeira-Neto E, Troiani HE, Schreiber A, Serquis AC. Degradation of oxygen reduction reaction kinetics in porous $\mathrm{La} 0.6 \mathrm{Sr} 0.4 \mathrm{Co} 0.2 \mathrm{Fe} 0.8 \mathrm{O} 3-\delta$ cathodes due to aging-induced changes in surface chemistry.pdf. J Power Sources 2017;337:166-72.

[26] Knibbe R, Hauch A, Hjelm J, Ebbesen SD, Mogensen M. Durability of Solid Oxide Cells. Green 2011;1:141-69. https://doi.org/10.1515/green.2011.015.

[27] Morales M, Miguel-Pérez V, Tarancón A, Slodczyk A, Torrell M, Ballesteros B, et al. Multiscale analysis of the diffusion barrier layer of gadolinia-doped ceria in a solid oxide fuel cell operated in a stack for $3000 \mathrm{~h}$. J Power Sources 2017;344:141-51. https://doi.org/10.1016/j.jpowsour.2017.01.109.

[28] The D, Grieshammer S, Schroeder M, Martin M, Al Daroukh M, Tietz F, et al. Microstructural comparison of solid oxide electrolyser cells operated for $6100 \mathrm{~h}$ and $9000 \mathrm{~h}$. J Power Sources 2015;275:901-11. https://doi.org/10.1016/j.jpowsour.2014.10.188.

[29] Yang J, Chen L, Cai D, Zhang H, Wang J, Guan W. Study on the strontium segregation behavior of lanthanum strontium cobalt ferrite electrode under compression. Int J Hydrogen Energy 2021;46:9730-40. https://doi.org/10.1016/j.ijhydene.2020.12.228.

[30] Sun Y, He S, Saunders M, Chen K, Shao Z, Jiang SP. A comparative study of surface segregation and interface of $\mathrm{La} 0 \cdot 6 \mathrm{Sr} 0 \cdot 4 \mathrm{Co} 0 \cdot 2 \mathrm{Fe} 0 \cdot 8 \mathrm{O} 3-\delta$ electrode on GDC and YSZ electrolytes of solid oxide fuel cells. Int J Hydrogen Energy 2021;46:2606-16. https://doi.org/10.1016/j.ijhydene.2020.10.113.

[31] Ferreira-Sanchez D, Grolimund D, Hubert M, Bleuet P, Laurencin J. A 2D and 3D X-ray mdiffraction and $\mathrm{m}$-fluorescence study of a mixed ionic electronic conductor. Int $\mathrm{J}$ Hydrogen Energy 2017;42:1203-11. https://doi.org/10.1016/j.ijhydene.2016.11.094.

[32] Knibbe R, Hjelm J, Menon M, Pryds N, Søgaard M, Wang HJ, et al. Cathode-electrolyte interfaces with CGO barrier layers in SOFC. J Am Ceram Soc 2010;93:2877-83. https://doi.org/10.1111/j.1551-2916.2010.03763.x.

[33] Szász J, Wankmüller F, Wilde V, Störmer H, Gerthsen D, Menzler NH, et al. Nature and Functionality of $\mathrm{La} 0.58 \mathrm{Sr} 0.4 \mathrm{Co} 0.2 \mathrm{Fe} 0.8 \mathrm{O} 3-\delta / \mathrm{Gd} 0.2 \mathrm{Ce} 0.8 \mathrm{O} 2-\delta / \mathrm{Y} 0.16 \mathrm{Zr} 0.84 \mathrm{O} 2-\delta$ Interfaces in SOFCs. J Electrochem Soc 2018;165:F898-906. https://doi.org/10.1149/2.0031811jes.

[34] Tsoga A, Gupta A, Naoumidis A, Nikolopoulos P. Gadolinia-Doped Ceria and Yttria Stabilized Zirconia Interfaces: Regarding Their Application for SOFC Technology. Acta 
Mater 2000;48:4709-14. https://doi.org/10.1016/S1359-6454(00)00261-5.

[35] Zhou XD, Scarfino B, Anderson HU. Electrical conductivity and stability of Gd-doped ceria/Y-doped zirconia ceramics and thin films. Solid State Ionics 2004;175:19-22. https://doi.org/10.1016/j.ssi.2004.09.040.

[36] Xu H, Cheng K, Chen M, Zhang L, Brodersen K, Du Y. Interdiffusion between gadolinia doped ceria and yttria stabilized zirconia in solid oxide fuel cells: Experimental investigation and kinetic modeling. J Power Sources 2019;441:227152. https://doi.org/10.1016/j.jpowsour.2019.227152.

[37] Wankmüller F, Szász J, Joos J, Wilde V, Störmer H, Gerthsen D, et al. Correlative tomography at the cathode/electrolyte interfaces of solid oxide fuel cells. J Power Sources 2017;360:399-408. https://doi.org/10.1016/j.jpowsour.2017.06.008.

[38] Wilde V, Störmer H, Szász J, Wankmüller F, Ivers-Tiffée E, Gerthsen D. Gd0.2Ce0.8O2 Diffusion Barrier Layer between (La0.58Sr0.4)(Co0.2Fe0.8)O3- $\delta$ Cathode and Y0.16Zr0.84O2 Electrolyte for Solid Oxide Fuel Cells: Effect of Barrier Layer Sintering Temperature on Microstructure. ACS Appl Energy Mater 2018;1:6790-800. https://doi.org/10.1021/acsaem.8b00847.

[39] Matsui T, Li S, Inoue Y, Yoshida N, Muroyama H, Eguchi K. Degradation Analysis of Solid Oxide Fuel Cells with $(\mathrm{La}, \mathrm{Sr})(\mathrm{Co}, \mathrm{Fe}) \mathrm{O} 3-\delta$ Cathode/Gd2O3-CeO2 Interlayer/Y2O3-ZrO2 Electrolyte System: The Influences of Microstructural Change and Solid Solution Formation. J Electrochem Soc 2019;166:F295-300. https://doi.org/10.1149/2.0841904jes.

[40] Shimura T, He A, Shikazono N. Evaluation of La0.57Sr0.38Co0.2Fe0.8O3- $\delta$ Electrode Performance Degradation Based on Three-Dimensional Microstructure Reconstruction and Electrochemical Simulation. J Electrochem Soc 2019;166:F821-30. https://doi.org/10.1149/2.1091912jes.

[41] Endler C, Leonide A, Weber A, Tietz F, Ivers-Tiffée E. Time-Dependent Electrode Performance Changes in Intermediate Temperature Solid Oxide Fuel Cells. J Electrochem Soc 2010;157:B292. https://doi.org/10.1149/1.3270047.

[42] DiGiuseppe G, Thompson D, Gumeci C, Hussain AM, Dale N. Distribution of relaxation times analysis and interfacial effects of LSCF fired at different temperatures. Int J Hydrogen Energy 2019;44:27067-78. https://doi.org/10.1016/j.ijhydene.2019.08.160.

[43] Finsterbusch M, Lussier A, Schaefer JA, Idzerda YU. Electrochemically driven cation segregation in the mixed conductor $\mathrm{La} 0.6 \mathrm{Sr} 0.4 \mathrm{Co} 0.2 \mathrm{Fe} 0.8 \mathrm{O} 3-$ delta. Solid State Ionics 2012;212:77-80.

[44] Mahmoud A, Daroukh M Al, Lipinska-Chwalek M, Luysberg M, Tietz F, Hermann RP. A 
Mössbauer spectral study of degradation in La0.58Sr0.4Fe0.5Co0.5O3-x after long-term operation in solid oxide electrolysis cells. Solid State Ionics 2017;312:38-43.

[45] Rinaldi G, Nakajo A, Van herle J, Burdet P, Oveisi E, Cantoni M. Strontium Migration at the GDC-YSZ Interface of Solid Oxide Cells in SOFC and SOEC Modes. ECS Trans 2017;78:3297-307. https://doi.org/10.1149/07801.3297ecst.

[46] Huang QA, Hui R, Wang B, Zhang J. A review of AC impedance modeling and validation in SOFC diagnosis. Electrochim Acta 2007;52:8144-64. https://doi.org/10.1016/j.electacta.2007.05.071.

[47] Papurello D, Menichini D, Lanzini A. Distributed relaxation times technique for the determination of fuel cell losses with an equivalent circuit model to identify physicochemical processes. Electrochim Acta 2017;258:98-109. https://doi.org/10.1016/j.electacta.2017.10.052.

[48] Costamagna P, Sala EM, Zhang W, Lund Traulsen M, Holtappels P. Electrochemical impedance spectroscopy of $\mathrm{La} 0.6 \mathrm{Sr} 0.4 \mathrm{Co} 0.2 \mathrm{Fe} 0.8 \mathrm{O} 3-\delta$ nanofiber cathodes for intermediate temperature-solid oxide fuel cell applications: A case study for the 'depressed' or 'fractal' $\begin{array}{llll}\text { Gerischer element. } & \text { Electrochim }\end{array}$ https://doi.org/10.1016/j.electacta.2019.06.068.

[49] Sonn V, Leonide A, Ivers-Tiffée E. Combined Deconvolution and CNLS Fitting Approach Applied on the Impedance Response of Technical Ni8YSZ Cermet Electrodes. J Electrochem Soc 2008;155:B675-9. https://doi.org/10.1149/1.2908860.

[50] Leonide A, Sonn V, Weber A, Ivers-Tiffée E. Evaluation and Modeling of the Cell Resistance in Anode-Supported Solid Oxide Fuel Cells. J Electrochem Soc 2008;155:B36. https://doi.org/10.1149/1.2801372.

[51] Caliandro P, Nakajo A, Diethelm S, Van herle J. Model-assisted identification of solid oxide cell elementary processes by electrochemical impedance spectroscopy measurements. J Power Sources 2019;436:226838. https://doi.org/10.1016/j.jpowsour.2019.226838.

[52] Shin EC, Ahn PA, Seo HH, Jo JM, Kim SD, Woo SK, et al. Polarization mechanism of high temperature electrolysis in a Ni-YSZ/YSZ/LSM solid oxide cell by parametric impedance analysis. Solid State Ionics 2013;232:80-96. https://doi.org/10.1016/j.ssi.2012.10.028.

[53] Liu B, Muroyama H, Matsui T, Tomida K, Kabata T, Eguchi K. Analysis of Impedance Spectra for Segmented-in-Series Tubular Solid Oxide Fuel Cells. J Electrochem Soc 2010;157:B1858. https://doi.org/10.1149/1.3494214.

[54] Nechache A, Mansuy A, Petitjean M, Mougin J, Mauvy F, Boukamp BA, et al. Diagnosis of a cathode-supported solid oxide electrolysis cell by electrochemical impedance spectroscopy. 
Electrochim Acta 2016;210:596-605. https://doi.org/10.1016/j.electacta.2016.05.014.

[55] Khamidy NI, Laurencin J, Ferreira-Sanchez D, Monaco F, Charlot F, Djurado E. Durability of nanostructured $\mathrm{LaPrNiO} 4+\delta$ electrode for solid oxide cells: Electrochemical, microstructural, and structural investigation. J Power Sources 2020;450:227724. https://doi.org/10.1016/j.jpowsour.2020.227724.

[56] Tao T, Ro J, Melngailis J, Xue Z, Kaesz HD. Focused ion beam induced deposition of platinum. J Vac Sci Technol B 1990;8:1826. https://doi.org/10.1116/1.585167.

[57] Kieffer J, Karkoulis D. PyFAI, a versatile library for azimuthal regrouping. J Phys Conf Ser 2013;425:202012. https://doi.org/10.1088/1742-6596/425/20/202012.

[58] Solé VA, Papillon E, Cotte M, Walter P, Susini J. A multiplatform code for the analysis of energy-dispersive X-ray fluorescence spectra. Spectrochim Acta - Part B At Spectrosc 2007;62:63-8. https://doi.org/10.1016/j.sab.2006.12.002.

[59] De Nolf W, Vanmeert F, Janssens K. XRDUA: Crystalline phase distribution maps by twodimensional scanning and tomographic (micro) X-ray powder diffraction. J Appl Crystallogr 2014;47:1107-17. https://doi.org/10.1107/S1600576714008218.

[60] Fang Q, Frey CE, Menzler NH, Blum L. Electrochemical Performance and Preliminary PostMortem Analysis of a Solid Oxide Cell Stack with 20,000 h of Operation. J Electrochem Soc 2018;165:F38-45. https://doi.org/10.1149/2.0541802jes.

[61] Frey CE, Fang Q, Sebold D, Blum L, Menzler NH. A Detailed Post Mortem Analysis of Solid Oxide Electrolyzer Cells after Long-Term Stack Operation. J Electrochem Soc 2018;165:F357-64. https://doi.org/10.1149/2.0961805jes.

[62] Hoerlein MP, Riegraf M, Costa R, Schiller G, Friedrich KA. A parameter study of solid oxide electrolysis cell degradation: Microstructural changes of the fuel electrode. Electrochim Acta 2018;276:162-75. https://doi.org/10.1016/j.electacta.2018.04.170.

[63] Tsoga A, Gupta A, Stöver D. Performance characteristics of composite film electrolytes for intermediate-temperature solid oxide fuel cells. Ionics (Kiel) 1999;5:175-82. https://doi.org/10.1007/BF02375837.

[64] Rinaldi G, Diethelm S, Oveisi E, Burdet P, Van herle J, Montinaro D, et al. Post-test Analysis on a Solid Oxide Cell Stack Operated for 10,700 Hours in Steam Electrolysis Mode. Fuel Cells 2017;17:541-9. https://doi.org/10.1002/fuce.201600194.

[65] Blum L, Fang Q, Groß-Barsnick SM, de Haart LGJ (Bert., Malzbender J, Menzler NH, et al. Long-term operation of solid oxide fuel cells and preliminary findings on accelerated testing. Int J Hydrogen Energy 2020;45:8955-64. https://doi.org/10.1016/j.ijhydene.2020.01.074.

[66] Fang Q, Blum L, Stolten D. Electrochemical Performance and Degradation Analysis of an 
SOFC Short Stack Following Operation of More than 100,000 Hours. J Electrochem Soc 2019;166:1320-5. https://doi.org/10.1149/2.0751916jes.

[67] Blum L, de Haart LGJ, Malzbender J, Margaritis N, Menzler NH. Anode-Supported Solid Oxide Fuel Cell Achieves 70’000 Hours of Continuous Operation. Energy Technol 2016;4:939-42. https://doi.org/10.1002/ente.201600114.

[68] Menzler NH, Sebold D, Sohn YJ, Zischke S. Post-test characterization of a solid oxide fuel cell after more than 10 years of stack testing. J Power Sources 2020;478:228770. https://doi.org/10.1016/j.jpowsour.2020.228770.

[69] Menzler NH, Sebold D, Guillon O. Post-test characterization of a solid oxide fuel cell stack operated for more than 30,000 hours: The cell. J Power Sources 2018;374:69-76. https://doi.org/10.1016/j.jpowsour.2017.11.025.

[70] Villanova J, Schlabach S, Brisse A, Léon A. X-ray fluorescence nano-imaging of long-term operated solid oxide electrolysis cells. J Power Sources 2019;421:100-8. https://doi.org/10.1016/j.jpowsour.2019.02.084.

[71] Uhlenbruck S, Moskalewicz T, Jordan N, Penkalla HJ, Buchkremer HP. Element interdiffusion at electrolyte-cathode interfaces in ceramic high-temperature fuel cells. Solid State Ionics 2009;180:418-23. https://doi.org/10.1016/j.ssi.2009.01.014.

[72] Wilde V, Störmer H, Szász J, Wankmüller F, Ivers-Tiffée E, Gerthsen D. Effect of Gd0.2Ce0.8O2 Sintering Temperature on Formation of a SrZrO3 blocking Layer between Y0.16Zr0.84O2, Gd0.2Ce0.8O2 and La0.58Sr0.4Co0.2Fe0.8O3. ECS Trans 2015;66:103-7.

[73] Leib EW, Pasquarelli RM, Blankenburg M, Müller M, Schreyer A, Janssen R, et al. HighTemperature Stable Zirconia Particles Doped with Yttrium, Lanthanum, and Gadolinium. Part Part Syst Charact 2016;33:645-55. https://doi.org/10.1002/ppsc.201600069.

[74] Katamura J, Seki T, Samuka T. The Cubic-Tetragonal Phase Equilibria in the ZrO2-R2O3 (R = Y, Gd, Sm, Nd) Systems. J Phase Equilibria 1995;16:315-9.

[75] Rebollo NR, Fabrichnaya O, Levi CG. Phase stability of Y + Gd co-doped zirconia. Zeitschrift Fuer Met Res Adv Tech 2003;94:163-70. https://doi.org/10.3139/146.030163.

[76] Basu S, Varma S, Shirsat AN, Wani BN, Bharadwaj SR, Chakrabarti A, et al. X-ray absorption spectroscopy of doped ZrO2 systems. J Appl Phys 2012;111. https://doi.org/10.1063/1.3693470.

[77] Lee YH, Sheu HS, Deng JP, Kao HCI. Preparation and fluorite-pyrochlore phase transformation in Gd2Zr2O7. J Alloys Compd 2009;487:595-8. https://doi.org/10.1016/j.jallcom.2009.08.021.

[78] Vaisakhan Thampi DS, Prabhakar R. P., A. Renju UA. Influence of aliovalent cation 
substitution on structural and electrical properties of $\operatorname{Gd} 2(\mathrm{Zr} 1-\mathrm{xMx}) 2 \mathrm{O} 7-\delta(\mathrm{M}=\mathrm{Sc}, \mathrm{Y})$ systems. RSC Adv 2015;5:88675.

[79] Yamamura H, Nishino H, Kakinuma K, Nomura K. Electrical conductivity anomaly around fluorite-pyrochlore phase boundary. Solid State Ionics 2003;158:359-65.

[80] Tsoga A, Naoumidis A, Jungen W, Stöver D. Processing and characterisation of fine crystalline ceria gadolinia-yttria stabilized zirconia powders. J Eur Ceram Soc 1999;19:90712. https://doi.org/10.1016/s0955-2219(98)00342-2.

[81] Hardy JS, Templeton JW, Edwards DJ, Lu Z, Stevenson JW. Lattice expansion of LSCF6428 cathodes measured by in situ XRD during SOFC operation. J Power Sources 2012;198:76-82. https://doi.org/10.1016/j.jpowsour.2011.09.099.

[82] Mineshige A, Izutsu J, Nakamura M, Nigaki K, Abe J, Kobune M, et al. Introduction of Asite deficiency into $\mathrm{La} 0.6 \mathrm{Sr} 0.4 \mathrm{Co} 0.2 \mathrm{Fe} 0.8 \mathrm{O} 3-\delta$ and its effect on structure and conductivity. Solid State Ionics 2005;176:1145-9. https://doi.org/10.1016/j.ssi.2004.11.021.

[83] Świerczek K, Dabrowski B, Suescun L, Kolesnik S. Crystal structure and magnetic properties of high-oxygen pressure annealed Sr1-xLaxCo0.5Fe0.5O3- $\delta(0 \leq \mathrm{x} \leq 0.5)$. J Solid State Chem 2009;182:280-8. https://doi.org/10.1016/j.jssc.2008.10.030.

[84] Bekale VM, Huntz AM, Legros C, Sattonnay G, Jomard F. Impurity diffusion of cerium and gadolinium in single- and polycrystalline yttria-stabilized zirconia. Philos Mag 2008;88:119. https://doi.org/10.1080/14786430701708331. 